\title{
A Review of Test Methods for Determining Protective Capabilities of Fire Fighter Protective Clothing from \\ Steam
}

Shonali Nazaré

Daniel Madrzykowski

February 2015

National Institute of 


\title{
A Review of Test Methods for Determining Protective Capabilities of Fire Fighter Protective Clothing from \\ Steam
}

\author{
Shonali Nazaré \\ Daniel Madrzykowski \\ Fire Research Division \\ Engineering Laboratory
}

February 2015

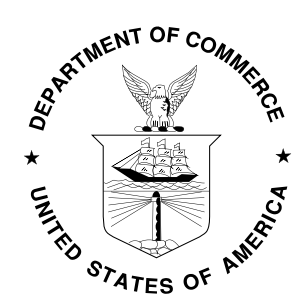

U.S. Department of Commerce

Penny Pritzker, Secretary 
Certain commercial entities, equipment, or materials may be identified in this document in order to describe an experimental procedure or concept adequately. Such identification is not intended to imply recommendation or endorsement by the National Institute of Standards and Technology, nor is it intended to imply that the entities, materials, or equipment are necessarily the best available for the purpose.

National Institute of Standards and Technology Technical Note 1861 Natl. Inst. Stand. Techn. Techn. Report 1861, 36 pages (February 2015) CODEN: NTNOEF

This publication is available free of charge from: http://dx.doi.org/10.6028/NIST.TN.1861 


\begin{abstract}
Firefighters working inside a burning structure often experience burns related to hot water vapor inside firefighter protective clothing (FFPC). For these burns to occur, the water vapor is heated by the high temperatures outside the FFPC and it diffuses across the FFPC fabric layers. Condensation of this vapor on the firefighter's cooler skin releases the water's latent heat of vaporization, rapidly raising the temperature of the skin. Burns from this moisture-driven heat transfer are often called "steam burns."

The water vapor can come from humidity in the burning-structure environment that penetrates through the outer shell of the FFPC. The humidity arises from firefighter water sprays and from combustion (which produces water vapor as a byproduct). The water vapor can also come from firefighter perspiration. The moisture, through a wicking process, spreads to the outer layers of the FFPC, where it is vaporized from a flashover exposure.

In this technical note, we review existing test methods for quantifying steam burns and evaluating moisture-driven heat transfer in protective clothing are reviewed, with an emphasis on the instrumentation, methodology, merits, and limitations of each method. We discuss bench-scale test methods using pre-wetted samples (simulating perspiration-sourced water vapor) as well as those using external steam exposures (simulating water vapor from humid environments). Gaps in test methodology are identified and suggestions for improvements in bench scale testing are made. From this review, we note that research on moisture-driven heat transfer through FFPC has primarily focused on perspiration-sourced water vapor. Better bench scale test methods are needed for quantifying the moisture-driven heat transfer through FFPC resulting from the humidity in environments such as those encountered during interior firefighting.
\end{abstract}

\title{
Keywords
}

Fire suppression; water vapor; steam burns; heat and mass transfer; fire fighter's protective clothing; thermal protective performance. 
This page left intentionally blank. 


\section{Contents}

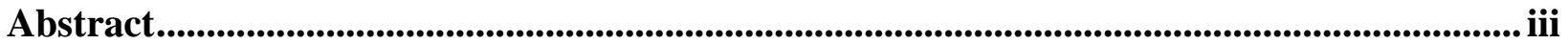

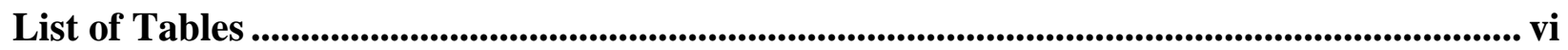

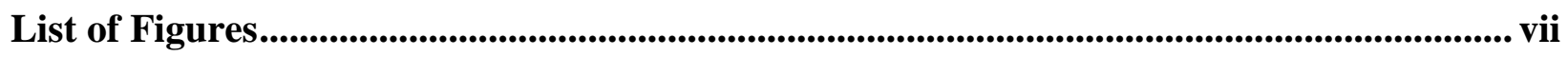

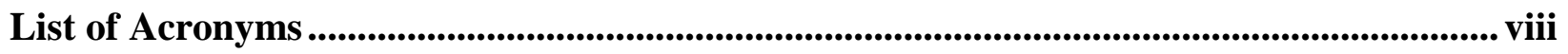

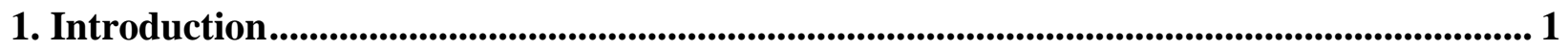

1.1. Humidity and steam-burn fundamentals ................................................................. 2

1.2. Fire fighters' protective clothing and its thermophysical properties .............................. 3

2. Heat and Moisture Transport Mechanisms in FFPC ............................................................ 7

2.1. Factors affecting heat and moisture transfer in FFPC …............................................. 8

3. Existing Test Methods to Assess Heat and Mass Transfer in FFPC ............................... 10

3.1. Test methods with moisture from pre-wetted samples......................................... 13

3.2. Test methods with moisture from external steam exposures ................................... 18

4. Summary and Conclusions ......................................................................................................... 23

5. References ........................................................................................................................ 25 


\section{List of Tables}

Table 1. Physical and thermal properties of typical fabrics used in FF turnout gear $[15,16] \ldots \ldots \ldots .4$

Table 2. Thermophysical properties of fabric and fabric assemblies used in FFPC [18] ............. 6

Table 3. Standards for evaluating comfort characteristics of FFPC ….................................. 11

Table 4. Standards for evaluating thermal protective performance of FFPC ........................... 12

Table 5. Moisture add-on levels and corresponding fire fighter conditions [32] ...................... 13

Table 6. Steam exposure conditions previously studied ...................................................... 23 


\section{List of Figures}

Figure 1. Schematic of heat and moisture transfer process associated with a typical fire suppression scenario

Figure 2. Test set up to measure thermal protective performance for low-level radiant exposures 14

Figure 3. Test apparatus to assess radiant protective performance of fabrics [27] 15

Figure 4. Schematic of experimental set up to assess protective performance of fabrics exposed to open flame [28] 16

Figure 5. Schematic of test set-up to assess protective performance of pre-wetted fabrics [8].... 17 Figure 6. Schematic of test apparatus to measure temperature distribution in a clothing assembly exposed to low thermal radiations [34]... 18

Figure 7. Schematic of bench scale test device with (a) steam jet and (b) steam atmosphere configurations [36].

Figure 8. Schematic of experimental set up to assess protective performance of fabrics exposed to external pressurized steam [31] 21

Figure 9. Schematic of TPP test apparatus with modified specimen assembly to accommodate microclimate between the specimen and the copper calorimeter [30]. 22

Figure 10. Apparatus for evaluation of fabric protection against industrial steam hazard [38] ... 23 


$\begin{array}{ll}\text { List of Acronyms } & \\ \text { ASTM } & \text { ASTM International } \\ \text { CCHR } & \text { Conductive Compressive Heat Resistance } \\ \text { DMPC } & \text { Dynamic Moisture Permeation Cell } \\ \text { FF } & \text { Fire Fighter } \\ \text { FFPC } & \text { Fire Fighters Protective Clothing } \\ \text { IMO } & \text { International Standards Organization } \\ \text { MB } & \text { Moisture Barrier } \\ \text { NFPA } & \text { National Fire Protection Association } \\ \text { OS } & \text { Outer Shell } \\ \text { PBO } & \text { Polyphenylenebenzobisozazole } \\ \text { PBI } & \text { Polybenzimidazole } \\ \text { PEEK } & \text { Polyether ether ketone } \\ \text { PPI } & \text { Poly(m-phenylene isophthalamide) } \\ \text { PPT } & \text { Poly(p-phenylene terephthalamide) } \\ \text { PTFE } & \text { Polytetrafluoroethylene } \\ \text { RH } & \text { Relative Humidity } \\ \text { RPP } & \text { Radiant Protective Performance } \\ \text { STE } & \text { Stored Thermal Energy } \\ \text { STI } & \text { Steam Transfer Index } \\ \text { T } & \text { Temperature } \\ \text { THL } & \text { Total Heat Loss } \\ \text { TL } & \text { Thermal Liner } \\ \text { TPP } & \text { Thermal Protective Performance } \\ \text { WVTR } & \text { Water Vapor Transmission Rate }\end{array}$




\section{Introduction}

Fire fighters working inside a burning structure are exposed to a hot and wet environment. As common household furnishings and interior finishes burn, one of the combustion products is water vapor. As fire fighters work to extinguish the fire using water sprays, water vapor inside the fire room may increase. This water vapor is commonly addressed as steam. Pure steam is a transparent gas that is formed by heating water at a temperature of $100^{\circ} \mathrm{C}$ and is not generally seen by the human eye [1]. The white cloud that forms along with the steam is mostly made up of tiny water particles that are formed due to condensation of steam in the air. The water vapor and/or water droplet temperature is below the boiling point of water $100{ }^{\circ} \mathrm{C} \mathrm{but} \mathrm{higher} \mathrm{than} \mathrm{the} \mathrm{temperature} \mathrm{at}$ which irreversible skin damage could occur $\left(\mathrm{T}>48^{\circ} \mathrm{C}\right)$.

When the fire fighters' protective clothing (FFPC) is exposed to external steam or an environment with high vapor concentration, then a concentration gradient may serve as a driving force for transfer of moisture from the environment with higher humidity to the environment having the lower humidity. As the humidity of the surrounding environment increases, the clothing system absorbs moisture, which may then diffuse across the fabric layers. These two processes continue until the clothing system is completely saturated and is dependent on water vapor temperature, fabric temperature, and types of fabric in the clothing system [2]. Additionally, prolonged exposure to high temperature environments can quickly raise the temperature of protective clothing and the skin underneath it. Even after the fire is extinguished, the skin temperature may still keep increasing. This is because of the energy stored within the fabric, the air gaps between the fabric layers, and the air gap between garment and the wearer's skin during the heat exposure. Furthermore, due to the high heat capacity of water, moisture in a clothing system increases the amount of stored energy [3]. This is particularly true when moist clothing is exposed to low heat flux conditions for longer durations.

The temperature of the water vapor to which the FFPC is exposed is lower than that of steam $\left(100{ }^{\circ} \mathrm{C}\right)$ but could be significantly higher than the skin temperature. Under such conditions, condensation could occur as the water vapor comes in contact with skin. Water thus formed may conduct heat with dangerous and unpredictable efficiency. Condensation of water vapor releases the latent heat of evaporation, which causes increased fabric and skin temperatures and can lead to skin burns, often referred to as steam burns. The human skin experiences discomfort or pain at about $44{ }^{\circ} \mathrm{C}$ [4]. However, Rossi [5] reported a firefighter suffering burn injuries at a measured skin temperature of $42{ }^{\circ} \mathrm{C}$. Burn injuries result when the temperature of the skin cells becomes high enough for the proteins to undergo a physical change. This process occurs at temperatures around $48^{\circ} \mathrm{C}$ and thereafter the rate of damage increases exponentially with temperature [6]. The progression of a burn injury is largely related to the amount of time the skin temperature is above $44^{\circ} \mathrm{C}$. The rate at which damage occurs is roughly tripled for each degree the skin cells are above this threshold temperature [7].

Studies have shown that wet protective clothing has a $50 \%$ higher heat transfer rate compared to that of dry protective gear [8]. In presence of moisture, the rate of heat transfer is much faster [9] and since skin is permeable to water vapor, studies [10] on pig skin have suggested that part of the steam may be absorbed by the skin leading to more severe burns than dry burns. Moreover, studies 
by Veghte [9] have shown that once a fire fighter begins to sweat, he/she becomes susceptible to moisture-related thermal injuries.

To date, there are very few studies examining the ability of FFPC to protect the wearer from steam burns. The issue of steam burns is not adequately addressed by the National Fire Protection Association (NFPA) 1971 Standard on Protective Ensembles for Structural Fire Fighting and Proximity Fire Fighting standard, which uses the thermal protective performance (TPP) index to specify the minimum thermal performance of structural firefighting ensembles (a dry test). Based on these requirements, the design of protective clothing is largely based on engineering protective performance to mitigate flash-fire exposures. Such an ensemble may not always protect the wearer from extended low-heat flux radiant exposures, particularly in the presence of moisture.

Previous research on heat and moisture transfer mechanisms has primarily focused on moisture generated due to excessive sweating of the firefighters and subsequent exposure to high-risk environments including flash-over exposures. The effect of external moisture and thereby the heat and moisture transfer through the protective clothing received very little attention. The main objective of this study is to understand the effects of external water vapor/steam exposures on protective performance of turnout gear. Existing test methods that quantify steam burn injuries have been reviewed and the gaps in test methodologies identified such that improvements in bench scale testing can be made. The long term goal is to develop a bench scale test method that quantifies heat and moisture diffusion through FFPC when fire fighters are exposed to an environment that simulates the thermal/water vapor conditions during interior fire fighting.

\subsection{Humidity and steam-burn fundamentals}

The phase change of water from liquid to vapor, which occurs at $100{ }^{\circ} \mathrm{C}$ at a pressure of $101325 \mathrm{~Pa}$ ( $1 \mathrm{~atm}$ ), is an endothermic process. The latent heat of vaporization (or the enthalpy of vaporization) for water is much greater than that of most other substances [11]. Properties of water-vapor/air mixtures that are relevant to this technical note are dew point and relative humidity. The dew point is the temperature at which water vapor condenses into liquid form, and depends on water concentration and pressure [12]. The dew point of pure water vapor is $100{ }^{\circ} \mathrm{C}$ but decreases as the water concentration decreases. Relative humidity is the ratio of actual water concentration to dew-point water concentration, and depends on water concentration, pressure and temperature [12]. It is usually expressed as a percentage. Relative humidity of $100 \%$ indicates the dew point is equal to the current temperature and that the air is maximally saturated with water. Since most structural/residential fires occur at atmospheric pressure, the properties of watervapor/air mixtures primarily depend on water concentration and temperature.

The phase change of water from vapor to liquid through condensation results in a decrease in its enthalpy and is therefore an exothermic process. Consequently, moist air has a great capacity to heat any surface or object that is cooler than its dew point. Condensation of steam to a liquid transfers all of the latent heat to the cooler object. In other words, a firefighter with a body temperature $\left(<37.7^{\circ} \mathrm{C}\right)$ is at great risk from steam burns from high dew-point water vapor if the vapor is inside the FFPC. 


\subsection{Fire fighters' protective clothing and its thermophysical properties}

Most turnout gear commonly used by firefighters in the United States is comprised of three layers, each performing a distinct function. The outer shell (OS) fabric provides flame protection and serves as a primary defense to mechanical injury, heat, and fire. The outer shell fabric is predominantly made from high performing, fire resistant fiber blends of poly (m-phenylene isophthalamide) (PPI), poly (p-phenylene terephthalamide) (PPT), polybenzimidazole (PBI), polyphenylenebenzobisozazole (PBO), and melamine. The waterproof middle layer, which often is a poly (tetrafluoroethylene) permeable film barrier laminated to a thin polyaramid woven or nonwoven backing substrate, acts as a moisture barrier (MB). The moisture barrier may totally prevent the passage of water droplets but permit the passage of water vapor. The permeability of the moisture barrier to water vapor generated from the perspiration of human skin has a strong influence on the water vapor transmission rate of FFPC and hence the body core temperature. Studies [12] have shown that the water vapor from human perspiration readily escapes through FFPC with a permeable moisture barrier and keeps the body core temperature lower by approximately $1{ }^{\circ} \mathrm{C}$ compared to FFPC with an impermeable moisture barrier. With an impermeable moisture barrier, water vapor pressure in the air gap between the skin and clothing layers increases and becomes saturated. Consequently, due to lack of heat exchange, a significant increase in air temperature and skin temperatures may be seen [13]. The thermal liner (TL) which is next to the skin provides thermal insulation and protects the wearer from burn injury. This layer typically consists of a nonwoven layer quilted to woven fabric, which slides easily along the skin or work station uniform (also known as station wear) to reduce the work required to move, and a spun-laced nonwoven insulating fabric.

The fabrics that constitute the three layers in turnout gear have varied fabric structure, fiber content and thermal properties. Physical and thermal properties including the thermal conductivity, specific heat capacity, and the thermo-optical properties of absorptivity, reflectivity, and transmissivity for representative fabrics used in turnout gear are given in Table $1[14,15]$. Thermal inertia (which is the product of density, heat capacity, and thermal conductivity) is another factor that determines heat transfer through fabrics and is largely influenced by the density of fabrics. Thermal conductivity relates to the rate of heat transfer through the material. Thermal conductivity of fabrics measured at ambient temperature fall within a narrow range of $0.03 \mathrm{~W} / \mathrm{m} \cdot \mathrm{K}$ to $0.08 \mathrm{~W} / \mathrm{m} \cdot \mathrm{K}$ and the average thermal conductivity values increase as exposure temperature and density of the fabrics increase. For outer shell fabric II in Table 1, thermal conductivity values of $0.12 \mathrm{~W} / \mathrm{m} \cdot \mathrm{K}$ at $450{ }^{\circ} \mathrm{C}$ have been registered by $\mathrm{Zhu}$ et al. [16]. They measured thermal conductivity values of protective fabrics when exposed to radiant heat. Thermal conductivity of dry fabrics is largely influenced by the amount of air (thermal conductivity of air at ambient temperature $=0.024 \mathrm{~W} / \mathrm{m} \cdot \mathrm{K}$ ) trapped within the fibers and the yarns. For wet conditions, the thermal conductivity of the fabric is influenced by the thermal conductivity of water $(0.56 \mathrm{~W} / \mathrm{m} \cdot \mathrm{K})$. 
Table 1. Physical and thermal properties of typical fabrics used in FF turnout gear $[14,15]$.

\begin{tabular}{|c|c|c|c|c|c|c|c|c|c|c|c|}
\hline \multirow[t]{2}{*}{ Properties* } & \multirow{2}{*}{\multicolumn{2}{|c|}{ Uncertainty }} & \multicolumn{3}{|c|}{ Outer shell } & \multicolumn{5}{|c|}{ Moisture barrier } & \multirow{2}{*}{$\begin{array}{l}\text { Thermal } \\
\text { liner } \\
\text { IX }\end{array}$} \\
\hline & & & I & II & III & IV & $\mathrm{V}$ & VI & VII & VIII & \\
\hline Thickness, mm & & & 1.32 & 0.82 & 0.80 & 1.22 & 1.12 & 0.52 & 0.96 & 0.80 & 3.59 \\
\hline Density, $\mathrm{kg} / \mathrm{m}^{3}$ & \multicolumn{2}{|l|}{ $\pm 10 \%$} & 519 & 317 & 322 & 121 & 179 & 317 & 143 & 322 & 74 \\
\hline \multirow{4}{*}{$\begin{array}{l}\text { Thermal } \\
\text { conductivity, } \\
\mathrm{W} / \mathrm{m} \cdot \mathrm{K}\end{array}$} & \multirow{4}{*}{$\begin{array}{ll} \pm & 11.7 \\
\% & \end{array}$} & $20^{\circ} \mathrm{C}$ & 0.0823 & 0.0483 & 0.0484 & 0.0340 & 0.0370 & 0.0352 & 0.0664 & 0.0423 & 0.0353 \\
\hline & & $48^{\circ} \mathrm{C}$ & 0.1020 & 0.0628 & 0.0697 & 0.0427 & 0.0433 & 0.0425 & 0.1172 & 0.0602 & 0.0445 \\
\hline & & $55^{\circ} \mathrm{C}$ & 0.1017 & 0.0679 & 0.0730 & 0.0441 & 0.0461 & 0.0479 & 0.1005 & 0.0621 & 0.0462 \\
\hline & & $72^{\circ} \mathrm{C}$ & 0.1081 & 0.0715 & 0.0838 & 0.0494 & 0.0476 & 0.0491 & 0.1248 & 0.0679 & 0.0494 \\
\hline $\begin{array}{l}\text { Specific heat } \\
\text { capacity, J/g. }{ }^{\circ} \mathrm{C}\end{array}$ & \multicolumn{2}{|l|}{ $\pm 54 \%$} & 1.62 & 1.75 & 1.24 & 2.28 & 2.07 & 1.24 & 1.53 & 2.05 & 1.75 \\
\hline \multirow[t]{2}{*}{ Reflectance $^{\S}$} & \multirow[t]{2}{*}{ \pm 0.011} & Front & \multirow[t]{2}{*}{0.223} & \multirow[t]{2}{*}{0.215} & \multirow[t]{2}{*}{0.219} & 0.437 & 0.113 & 0.268 & 0.159 & 0.239 & 0.236 \\
\hline & & Back & & & & 0.304 & 0.294 & 0.277 & 0.237 & 0.221 & 0.288 \\
\hline \multirow[t]{2}{*}{ Absorptance ${ }^{\S}$} & \multirow[t]{2}{*}{ \pm 0.018} & Front & \multirow[t]{2}{*}{0.673} & \multirow[t]{2}{*}{0.637} & \multirow[t]{2}{*}{0.661} & 0.439 & 0.759 & 0.545 & 0.707 & 0.537 & 0.643 \\
\hline & & Back & & & & 0.571 & 0.575 & 0.540 & 0.627 & 0.570 & 0.591 \\
\hline \multirow[t]{2}{*}{ Transmittance, } & \multirow{2}{*}{$\begin{array}{l} \pm \\
0.0035\end{array}$} & Front & \multirow[t]{2}{*}{0.718} & \multirow[t]{2}{*}{0.708} & \multirow[t]{2}{*}{0.713} & 0.672 & 0.732 & 0.719 & 0.724 & 0.715 & 0.714 \\
\hline & & Back & & & & 0.690 & 0.679 & 0.693 & 0.704 & 0.693 & 0.688 \\
\hline
\end{tabular}

I- $100 \%$ cotton fabric.

II- $93 \%$ meta-aramid, $5 \%$ para-aramid and $2 \%$ antistatic fiber blend fabric.

III- $40 \%$ polybenzimidazole (PBI) and $60 \%$ poly ( $p$-phenylene terephthalamide) (PPA) fiber blend fabric.

IV- Non-crosslinked polyurethane membrane laminated to polyaramid woven fabric.

V- Crosslinked polyurethane membrane laminated to polyaramid woven fabric.

VI- Microporous expanded polytetrafluoroethylene membrane laminated to polyaramid woven fabric.

VII- Non-breathable neoprene coated aramid fabric.

VIII- Microporous expanded polytetrafluoroethylene membrane laminated to polyaramid woven fabric.

IX- Poly aramid batting quilted with $100 \%$ meta-aramid woven fabric.

${ }^{\S}$ Values weighted with blackbody function at typical flame temperatures of $\approx 1127{ }^{\circ} \mathrm{C}(1400 \mathrm{~K})$.

${ }^{\ddagger}$ Values weighted with material temperature of $\approx 77^{\circ} \mathrm{C}(350 \mathrm{~K})$ 
Specific heat capacity values give the estimate of energy required to maintain a material at a given temperature. For fabrics used in turnout gear, the specific heat capacity varies between $1.24 \mathrm{~J} / \mathrm{g} \cdot{ }^{\circ} \mathrm{C}$ and $2.28 \mathrm{~J} / \mathrm{g} \cdot{ }^{\circ} \mathrm{C}$. For comparison, specific heat capacity of water, air, and steam is $1.00 \mathrm{~J} / \mathrm{g} \cdot{ }^{\circ} \mathrm{C}$, $0.24 \mathrm{~J} / \mathrm{g} \cdot{ }^{\circ} \mathrm{C}$, and $0.45 \mathrm{~J} / \mathrm{g} \cdot{ }^{\circ} \mathrm{C}$ respectively [9]. Water has a high specific heat compared to dry air, meaning that it takes much more energy to cause a change in the water temperature. For turnout gear, this essentially means that higher amount of energy is required to heat and cool wet gear compared to dry gear. The wet turnout gear also retains heat for a longer duration [14].

Optical properties relate how materials absorb, reflect, and transmit incident radiative energy. When thermal energy reaches a fabric surface, some may be reflected, some absorbed, and the remainder either conducted or transmitted through the fabric. Energy absorbed by the exposed surface of FFPC raises its temperature and produces a temperature gradient through the material. Thermo-optical data of fabrics is for new materials and is primarily used in computer modeling to predict thermal protective performance. It can be noted from the thermo-optical data in Table 1 that transmittance, which is the fraction of incident radiant energy transmitted through a material [14], for front and back faces of fabrics with different surface finishes and dyes was similar, whereas the differences in reflectance were substantial. Reflectivity is the fraction of energy reflected from a material and is generally low for textile materials [17]. Absorptivity is closely related to emissivity and is measured as a comparison to the emissive power of a black body at the same temperature. Absorptivity for nonmetallic materials is generally high and is low for polished metal surfaces [14].

The thermal protective performance of protective clothing is primarily based on the thickness, area density and type of fiber of the fabric. However, since the FFPC is made from a multi-layered fabric composite, the thermal protective performance of the clothing system cannot be estimated using a simple additive law. While such data for structural FFPC is not currently available, data for wildland fire fighter's protective clothing is used as an example. Thermophysical and transport properties of typical fabrics and fabric assemblies that are used for wildland firefighters are given in Table 2 [18]. It can be noted from Table 2 that simple additive law overestimates the radiant protective performance (RPP) of multi-layered fabric composite while thermal resistance increases linearly with the total thickness of the composite. The types of fiber and fabric weave have very little impact on thermal resistance of the fabric. The air permeability values in Table 2 suggest that an inverse additive law is applicable to predict permeability of fabric composites. The moisture evaporation rate however, is largely influenced by the number of layers and the thickness of the fabric assembly. Similar studies [19] of fabric assemblies have shown that moisture permeability of each layer is important and that the low permeability of any layer would lower the moisture evaporation rate of the fabric assembly. 
Table 2. Thermophysical properties of fabric and fabric assemblies used in FFPC [18]

\begin{tabular}{|c|c|c|c|c|c|c|c|c|}
\hline Code & Fiber & Weave & $\begin{array}{l}\text { Thickness, } \\
\mathrm{mm}\end{array}$ & $\begin{array}{l}\text { Weight, } \\
\mathrm{g} / \mathrm{m}^{2}\end{array}$ & $\begin{array}{l}\text { Air permeability, } \\
\mathrm{m}^{3} / \mathrm{min} / \mathrm{m}^{2}\end{array}$ & $\begin{array}{l}\text { Radiant } \\
\text { protective } \\
\text { performance } \\
(\mathrm{RPP}) \\
\mathrm{J} / \mathrm{cm}^{2}\end{array}$ & $\begin{array}{l}\text { Thermal } \\
\text { resistance, } \\
{ }^{\circ} \mathrm{C} / \mathrm{m}^{2} / \mathrm{W}\end{array}$ & $\begin{array}{l}\text { Moisture } \\
\text { evaporation, } \\
\mathrm{g} / \mathrm{m}^{2} \cdot \mathrm{h}\end{array}$ \\
\hline \multicolumn{9}{|c|}{ Single-layered fabrics } \\
\hline A & Cotton & Twill & 0.56 & 237 & 48 & 37.7 & 0.171 & 45 \\
\hline B & Poly aramid & basket & 0.55 & 187 & 67 & 33.5 & 0.161 & 54 \\
\hline $\mathrm{C}$ & $\begin{array}{l}\text { Cotton } 45 \% \text { I } \\
\text { modacrylic } 55 \%\end{array}$ & twill & 0.52 & 305 & 20 & 42.3 & 0.160 & 52 \\
\hline $\mathrm{D}$ & Poly aramid & Twill & 0.73 & 288 & 22 & 39.3 & 0.170 & 50 \\
\hline $\mathrm{E}$ & Cotton & knit & 0.56 & 237 & 156 & 33.9 & 0.169 & 50 \\
\hline \multicolumn{9}{|c|}{ Multilayered fabric composites } \\
\hline $\mathrm{B}+\mathrm{E}$ & - & - & 1.11 & - & 47 & 61.1 & 0.194 & 47 \\
\hline $\mathrm{B}+\mathrm{C}$ & - & - & 1.07 & - & 16 & 79.1 & 0.188 & 44 \\
\hline $\mathrm{B}+\mathrm{A}$ & - & - & 1.11 & - & 27 & 70.7 & 0.189 & 48 \\
\hline $\mathrm{B}+\mathrm{A}+\mathrm{E}$ & - & - & 1.64 & - & 15 & 83.7 & 0.202 & 32 \\
\hline
\end{tabular}




\section{Heat and Moisture Transport Mechanisms in FFPC}

Three types of heat transfer exist in a firefighting environment or any thermal environment that could cause skin burns: conduction, convection, and thermal radiation. Conduction is the direct transfer of heat through contact with the hot object. Convection is the transfer of heat through a moving medium, for example, flowing air. Thermal radiation is the radiative transfer of heat caused by the temperature difference between two facing surfaces, for example the surface of protective clothing and surrounding surfaces. Radiant heat becomes stored thermal energy as it is absorbed by the surfaces of protective clothing. As the stored thermal energy increases, it is transferred inward from the outer (shell) layer and may cause burn injuries.

Fire fighter protective clothing exposed to a prolonged severe fire undergoes three heating phases. During an initial warm-up phase, the temperature of the fibers in the fabric increases at a rate dictated by the system's thermal properties and by the intensity of the incident heat. The second heating phase is marked by the onset of changes in the thermal properties of the fabric. If the fiber does not melt, or the transition temperature is not exceeded, the structural integrity of the fabric system is maintained during this phase of heating. A third and final phase of the exposure is marked by chemical and structural degradation of the protective fabric. This phase is followed by rapid fabric decomposition or combustion. At this point, the garment is no longer protecting the wearer since the fabric itself becomes a source of off-gassing heat and flame.

Similarly a piece of dry fabric exhibits three stages of transport behavior in responding to external humid transients $[20,21]$. The first stage is dominated by two fast processes: water vapor diffusion and liquid water diffusion in the air filling the interfiber voids, which can reach steady states in a fraction of a second. During this period, water vapor diffuses into the fabric due to the concentration gradient across the two surfaces. The second stage features the moisture sorption of fibers, which is a relatively slow process and takes a few minutes to a few hours to complete, depending on the type of fibers and heat transfer processes. In this period, sorption of water into the fibers takes place as the water vapor diffuses into the fabric, which increases the relative humidity at the fiber surfaces. Finally, the third stage is reached as a steady state which is mainly dominated by liquid water transmission (liquid diffusion or capillary wicking) through a fabric. The steady state flow of liquid moisture is most strongly influenced by wettability (i.e., surface tension), fabric weave (pore distribution) and thickness of the fabric.

During fire suppression activities, heat and mass transfer processes are coupled by evaporation and condensation. These processes could occur on either side of the clothing system as shown in Fig1. Figure 1 depicts a scenario that is of interest to this work: a fire fighter involved in fire suppression activity is exposed to external heat and moisture flux and at the same time is sweating profusely to regulate body heat. It is important to note here that the FFPC includes layers of different types of fabrics with different thermophysical properties, air permeabilities, and water vapor resistances. Absorption, distribution, and transport of moisture originating from sweat depend on the presence of an underlying clothing layers (station wear and underwear), the type of thermal liner, and the breathability of the moisture barrier. The processes associated with this part of moisture transfer include wicking, evaporation and condensation. Whereas, absorption and diffusion of external moisture depend primarily on air and water vapor permeability of the outer shell and moisture barrier. Combined heat and moisture transfer in protective clothing represents 
a more complex phenomenon. Factors influencing heat and moisture transfer in FFPC are briefly discussed in the section below.

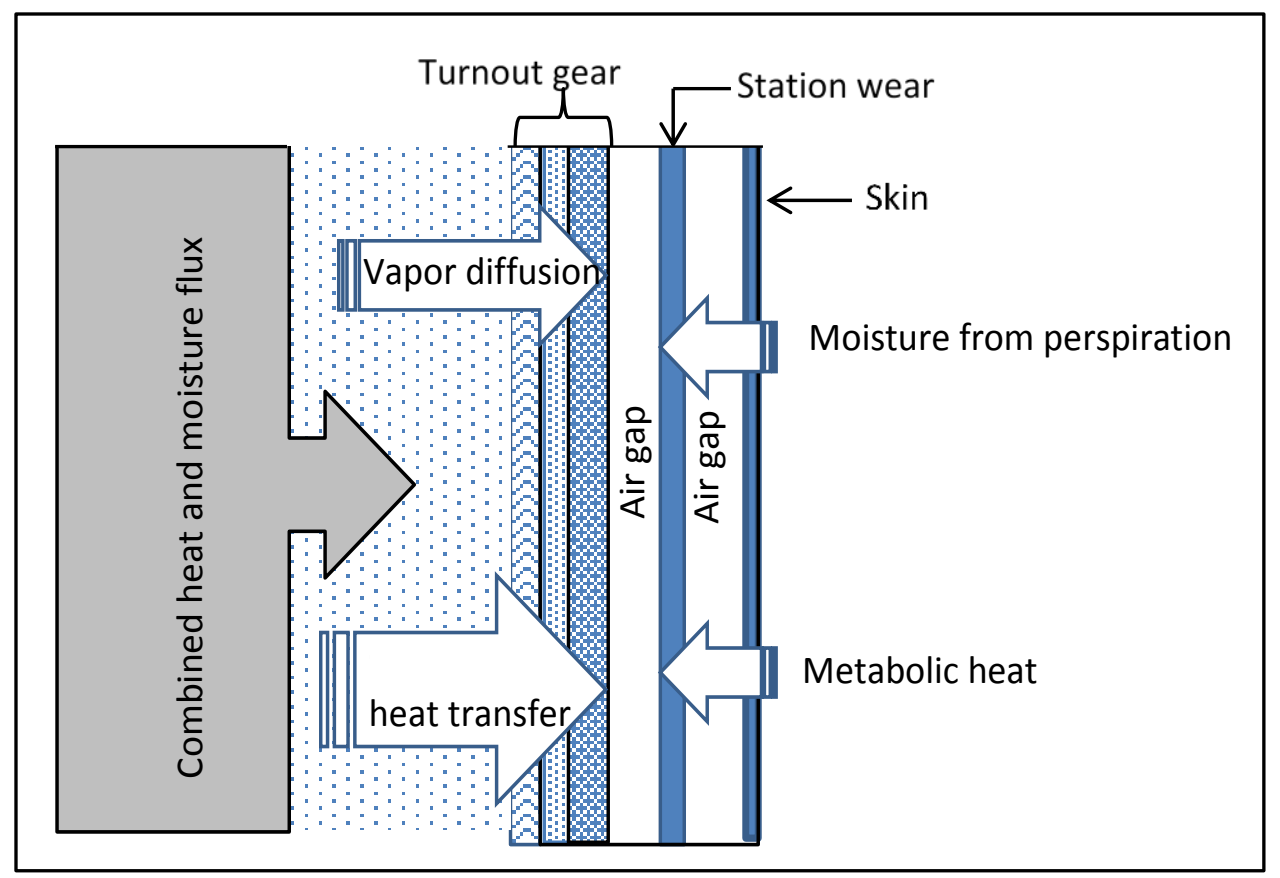

Figure 1. Schematic of heat and moisture transfer process associated with a typical fire suppression scenario

\subsection{Factors affecting heat and moisture transfer in FFPC}

Many researchers [8, 9,19, , 22, 23, 24, 25, 26, 27, 28, 29, 30, 31, 32, 33] have studied heat and moisture transfer in fire fighter's protective clothing. The range of studies include effects of high [3] and low heat exposures [3,32,34], location [3,8], and amount [3,30] of moisture in the clothing system on skin burns.

The presence of moisture in clothing systems can either increase or decrease the effectiveness of thermal insulation, depending on the nature of the heat exposure. Barker and Lee [26] explored the relationship between heat exposure conditions and moisture effects on thermal protective performance of single-layered high performance fabrics. They measured thermal protective performance of single-layered high performance fabrics by exposing dry and pre-wetted specimens to three different heat exposures; 1) $50 / 50$ radiant/convective heat flux of $84 \mathrm{~kW} / \mathrm{m}^{2}, 2$ ) $100 \%$ radiant heat flux of $20 \mathrm{~kW} / \mathrm{m}^{2}$, and 3) $100 \%$ radiant heat flux of $84 \mathrm{~kW} / \mathrm{m}^{2}$. The heat transferred through the fabric was measured by a copper calorimeter often referred to as a copper sensor [35]. They concluded that presence of moisture in flame-resistant fabrics enhances thermal protective performance as compared to dry fabrics, particularly when exposed to a combined radiant and convective heat flux of $84 \mathrm{~kW} / \mathrm{m}^{2}$. They suggested that convective action of flames has ablative effects. However, under high radiant heat fluxes, the radiant thermal energy and the water vapor are directly transported from the fabric to copper calorimeter thereby registering higher heat 
transfer rates. By contrast, when exposed to low radiant heat fluxes, reduced heat transfer to the copper calorimeter was recorded. The authors attributed lower heat transfer rates to the increased thermal capacity of pre-wetted fabrics.

Similar findings were reported by Lawson [3] and Zhu et al. [27]. Lawson [3] studied heat and moisture transfer in wildland firefighters' clothing systems by varying the amount and location of moisture. The fabric systems, comprised of outer wear and underwear, were subjected to two types of heat exposure including a high-heat-flux $\left(84 \mathrm{~kW} / \mathrm{m}^{2}\right)$ flame and a low-heat-flux $\left(10 \mathrm{~kW} / \mathrm{m}^{2}\right)$ radiant exposure. Their findings were very much in agreement with Barker et al. [26] revealing that the moisture could affect the thermal protective performance, either negatively or positively. For both, high-flaming (30/70 radiant/convective heat flux) and low-radiant heat exposures (100\% radiant), the moisture in the outer layers of the clothing system resulted in reduced heat transfer. The moisture in the outer layer evaporates and escapes from the fabric (away from the skin) to the external environment thereby registering low heat transfer though the clothing system. The moisture in the internal fabric layers however, responds differently to the two different heat exposures. With high-heat-flux, open-flame exposures, the moisture in internal layers was unable to escape the clothing system and consequently condensed on the copper calorimeter. The convective heat flux forces the heat energy towards the copper calorimeter thereby registering high heat transfer. When exposed to radiant heat flux, moisture in the internal layer absorbs most of the incident thermal energy and slows the heat transfer to the copper calorimeter.

Zhu et al. [27] developed a numerical model to predict heat and moisture transfer through singlelayered fabrics when exposed to low $\left(21 \mathrm{~kW} / \mathrm{m}^{2}\right)$ and high $\left(42 \mathrm{~kW} / \mathrm{m}^{2}\right)$ radiant heat fluxes. They validated their model experimentally and showed that moisture within the pre-wetted fabric decreases heat transfer to the skin-simulating sensor ${ }^{1}$ when exposed to the low radiant heat flux. The reduction in heat transfer to the skin simulant is again attributed to absorption of thermal energy by the moisture in the fabric. The authors also predicted that vapor density in the air gap between the fabric and skin simulant increases as it gains moisture from the pre-wetted fabric exposed to radiant heat flux. However, when the radiant heat source is shut down, the vapor density decreased. They presumed that the moisture in the air gap is transferred back to the fabric due to reduction of fabric temperature. In a separate study, Zhu and Zhou [28] concluded that the moisture evaporation rate increased due to rapid increase in fabric temperature. In their experiments they suggested that evaporated moisture from the fabric moves into the air gap and re-condensation of this water vapor releases heat thereby registering higher temperatures. The authors however, did not quantify the conditions of the microclimate produced in the air gap between the fabrics.

Studies on external, pressurized steam exposures $[36,37,38]$ reported that maximum heat transfer occurs at highest steam pressure and that the laminated and coated fabrics performed better than permeable fabrics. Permeable fabrics exhibit an instantaneous peak of heat flux on exposure to steam. However, Schimid et al. [36] noticed that impermeable fabrics progressively became permeable due to denaturation of coated layer when exposed to steam. The process of denaturation was not instantaneous but was dependent on the intensity of steam exposure. With regards to fabric properties that affect protective performance against external steam exposures, studies [36,

\footnotetext{
${ }^{1}$ Skin-simulating sensor uses a glass ceramic block instrumented with thermocouples. The glass ceramic block has thermal properties resembling to that of a human skin.
} 
37,38] have suggested that heat transfer during steam exposure depends primarily on fabric thickness, water vapor permeability, fabric structure, and insulative properties of fabrics. Sati et al. [37] noted that both steam pressure and distance between test specimen and the skin-simulating sensor significantly influence heat transfer.

Considering the complexity of heat and moisture transfer through clothing systems, the microclimate in the air gaps within the clothing system and between the clothing and the skin is expected to play a significant role. The effect of air gaps on heat $[39,40,41,42]$ and moisture $[23,24,27,28,30]$ transfer has been extensively studied. However, conditions of the microclimate have never been quantified. Better understanding of the properties of the microclimate can help understand steam diffusion mechanisms through the layers of FFPC and thereby the occurrence of steam burns in fire fighters. Furthermore, understanding contributions of different layers of FFPC on heat and moisture transfer are important. The role of finishes on water repellency and thereby the moisture absorption by the outer shell, permeability of moisture barriers to water vapor, and effects of the thermal liner on moisture accumulation need to be investigated.

\section{Existing Test Methods to Assess Heat and Mass Transfer in FFPC}

Assessment of heat and mass transfer in protective clothing has largely examined two topics: (a) comfort related to human perspiration and evaporation of sweat produced, and (b) thermal protection related to thermal damage of skin. Various test methods adopted by standards committees for protective clothing are given in Table 3 and Table 4. Standards listed in Table 3 correspond to the comfort (physiological) characteristics of protective clothing. These tests are designed to measure the ability of a fabric or fabric assemblies to transfer heat and moisture. These measurements can be used to quantify the relative capability of the garment to dissipate metabolic heat to the surrounding environment. The total heat loss (THL) value and the water vapor transmission resistance (WVTR) relate to breathability of a fabric or fabric assemblies. The description of test methods and test devices that quantify comfort properties is available elsewhere $[25,43,44,45]$ and is beyond the scope of this review. 
Table 3. Standards for evaluating comfort characteristics of FFPC

\begin{tabular}{|l|l|l|l|}
\hline Standard & $\begin{array}{l}\text { Material } \\
\text { tested }\end{array}$ & Test apparatus & Property evaluated \\
\hline $\begin{array}{l}\text { ASTM F 1868, Part C } \\
\text { [46]. }\end{array}$ & $\begin{array}{l}\text { Multi-layered } \\
\text { fabric } \\
\text { composite }\end{array}$ & $\begin{array}{l}\text { Sweating hot } \\
\text { plate }\end{array}$ & $\begin{array}{l}\text { Total heat loss, } \mathrm{W} / \mathrm{m}^{2} \\
\text { THL }>450 \mathrm{~W} / \mathrm{m}^{2}\end{array}$ \\
\hline ASTM E 96 [47] & $\begin{array}{l}\text { Multi-layered } \\
\text { fabric } \\
\text { composite }\end{array}$ & Dish/cup & $\begin{array}{l}\text { Water vapor transmission rate, } \\
\mathrm{g} / \mathrm{h}^{2} \mathrm{~m}^{2}\end{array}$ \\
\hline $\begin{array}{l}\text { ISO 11092-DIN EN } \\
\text { 31092 [48] }\end{array}$ & $\begin{array}{l}\text { Multi-layered } \\
\text { fabric } \\
\text { composite }\end{array}$ & $\begin{array}{l}\text { Sweating hot } \\
\text { plate }\end{array}$ & $\begin{array}{l}\text { Thermal resistance, } \mathrm{K} \cdot \mathrm{m}^{2} / \mathrm{W} \\
\text { Evaporative resistance, } \\
\mathrm{kPa} \cdot \mathrm{m}^{2} / \mathrm{W}\end{array}$ \\
\hline NFPA 1971 & $\begin{array}{l}\text { Moisture } \\
\text { barrier }\end{array}$ & WVTR cup & $\begin{array}{l}\mathrm{Water} \text { vapor transmission rate, } \\
\mathrm{g} / \mathrm{h} \cdot \mathrm{m}^{2}\end{array}$ \\
\hline ASTM F 1291 [49] & $\begin{array}{l}\text { Full clothing } \\
\text { system }\end{array}$ & $\begin{array}{l}\text { Sweating thermal } \\
\text { manikin }\end{array}$ & $\begin{array}{l}\text { Total thermal insulation, } \\
{ }^{\circ} \mathrm{C} \cdot \mathrm{m}^{2} / \mathrm{W}\end{array}$ \\
\hline ASTM F2370 [50] & $\begin{array}{l}\text { Full clothing } \\
\text { system }\end{array}$ & $\begin{array}{l}\text { Sweating thermal } \\
\text { manikin }\end{array}$ & $\begin{array}{l}\text { Evaporative resistance, } \\
\mathrm{kPa} \cdot \mathrm{m}^{2} / \mathrm{W}\end{array}$ \\
\hline ASTM F2371 [51] & $\begin{array}{l}\text { Full clothing } \\
\text { system }\end{array}$ & $\begin{array}{l}\text { Sweating Heated } \\
\text { Manikin }\end{array}$ & Average cooling rate, $\mathrm{W} / \mathrm{s}$ \\
\hline ASTM F 2298 [52] & $\begin{array}{l}\text { Fabric } \\
\text { specimen }\end{array}$ & $\begin{array}{l}\text { Dynamic } \\
\text { moisture } \\
\text { permeation cell } \\
\text { (DMPC) }\end{array}$ & $\begin{array}{l}\text { Water vapor transmission rate, } \\
\mathrm{g} / \mathrm{h} \cdot \mathrm{m}^{2}\end{array}$ \\
\hline ISO 15831 [53] & $\begin{array}{l}\text { Full clothing } \\
\text { system }\end{array}$ & Thermal manikin & Thermal insulation, ${ }^{\circ} \mathrm{C} \cdot \mathrm{m}^{2} / \mathrm{W}$ \\
\hline
\end{tabular}

Standards and test methods related to thermal protective performance of FFPC are listed in Table 4. These bench scale tests methods are usually designed to characterize performance of materials in given conditions and not necessarily to reproduce a particular hazard for e.g., steam burns. These test methods assess the properties of materials in pseudo equilibrium, i.e., they do not give any information on any of the dynamic properties of the test materials that may be important under transient conditions. Two such tests that are usually applied to FFPC materials are known commonly as "Thermal Protective Performance (TPP)" [54] and "Radiant Protective Performance (RPP)" [55]. Both of these test methods use a small sample of material which is exposed to a defined heat energy source and the heat energy transfer through the material is measured. The endpoint of the test is usually when the energy transfer is predicted to be just sufficient to result in a second degree burn injury (Stoll criteria [56]) or when a fixed amount of energy has been transferred through the material. These test methods use time to second degree burn as the criterion for evaluation of thermal protective performance, which is dependent on the rise in temperature and dry heat transfer. 
Table 4. Standards for evaluating thermal protective performance of FFPC

\begin{tabular}{|c|c|c|c|}
\hline Standard & Material tested & Test apparatus & Property evaluated \\
\hline ASTM F 2702 [57] & $\begin{array}{l}\text { Flame resistant } \\
\text { clothing materials }\end{array}$ & RPP test device & Heat transfer, $\mathrm{kW} / \mathrm{m}^{2}$ \\
\hline $\begin{array}{l}\text { ASTM F 2703[58] } \\
\text { NFPA } 1971[54]\end{array}$ & $\begin{array}{l}\text { Flame resistant } \\
\text { clothing materials }\end{array}$ & TPP test device & $\begin{array}{l}\text { Heat transfer, } \mathrm{kW} / \mathrm{m}^{2} \\
\text { Time to second degree } \\
\text { burn, } \mathrm{s}\end{array}$ \\
\hline ISO 17492 [59] & $\begin{array}{l}\text { Flame resistant } \\
\text { clothing materials }\end{array}$ & TPP device & $\begin{array}{l}\text { Heat transfer, } \mathrm{kW} / \mathrm{m}^{2} \\
\text { Time to second degree } \\
\text { burn, s }\end{array}$ \\
\hline $\begin{array}{l}\text { ASTM F1939 [60] } \\
\text { NFPA } 1977[55]\end{array}$ & $\begin{array}{l}\text { Flame resistant } \\
\text { clothing materials }\end{array}$ & RPP test device & $\begin{array}{l}\text { Heat transfer }, \mathrm{kW} / \mathrm{m}^{2} \text { or } \\
\text { RPP rating }\end{array}$ \\
\hline $\begin{array}{l}\text { ASTM F2731 [61] } \\
\text { NFPA } 1971[54]\end{array}$ & $\begin{array}{l}\text { Flame resistant } \\
\text { clothing materials }\end{array}$ & $\begin{array}{l}\text { Stored thermal } \\
\text { energy (STE) } \\
\text { device }\end{array}$ & $\begin{array}{l}\text { Heat transfer, } \mathrm{kW} / \mathrm{m}^{2} \\
\text { Time to second degree } \\
\text { burn, s }\end{array}$ \\
\hline ISO 9151[62] & $\begin{array}{l}\text { Flame resistant } \\
\text { clothing materials }\end{array}$ & $\begin{array}{l}\text { Flame exposure } \\
\text { apparatus }\end{array}$ & Heat transfer index \\
\hline $\begin{array}{l}\text { ASTM F } 1060 \text { [63] } \\
\text { NFPA } 1971[54]\end{array}$ & Clothing materials & $\begin{array}{l}\text { Conductive and } \\
\text { Compressive } \\
\text { Heat Resistance } \\
\text { (CCHR) test } \\
\text { device }\end{array}$ & $\begin{array}{l}\text { Heat absorption } \\
\text { Thermal conduction, } \\
\mathrm{W} / \mathrm{m} \cdot \mathrm{K}\end{array}$ \\
\hline ASTM F 1930 [64] & $\begin{array}{l}\text { Full clothing } \\
\text { system }\end{array}$ & $\begin{array}{l}\text { Instrumented } \\
\text { Manikin }\end{array}$ & $\begin{array}{l}\text { Heat transfer, } \mathrm{kW} / \mathrm{m}^{2} \\
\text { Time to second degree } \\
\text { burn, } \mathrm{s}\end{array}$ \\
\hline $\begin{array}{l}\text { ASTM F955 [65] } \\
\text { ISO 9185/BS373 [66] }\end{array}$ & Clothing materials & $\begin{array}{l}\text { Molten metal } \\
\text { exposure } \\
\text { apparatus }\end{array}$ & $\begin{array}{l}\text { Temperature rise, }{ }^{\circ} \mathrm{C} \\
\text { Time to second degree } \\
\text { burn, s } \\
\text { Visual rating for charring, } \\
\text { shrinkage, adherence and } \\
\text { perforation }\end{array}$ \\
\hline
\end{tabular}

Both test methods were originally designed to rate the materials used in protective clothing and not to measure the true protection offered by the clothing. A rating method is based on times to second degree burn criteria for a given heat flux exposure (TPP/RPP rating $=$ time to second degree burn $x$ incident heat flux). According to NFPA 1971, a TPP rating of 35 is required for a fabric assembly to be used in fire fighter turnout gear. A TPP rating of 35 essentially means that a fire fighter can withstand a flashover fire condition $\left(84 \mathrm{~kW} / \mathrm{m}^{2}\right)$ for $17.5 \mathrm{~s}$ without getting second degree burns. An RPP rating of 20 is specified by NFPA 1971 for a FFPC assembly which translates to $20 \mathrm{~s}$ protection time at approximately $42 \mathrm{~kW} / \mathrm{m}^{2}$ radiant exposure. European standards for protective clothing, however, measure the time to increase the skin temperature by $12{ }^{\circ} \mathrm{C}$ and $24^{\circ} \mathrm{C}$. This time does not provide any information about steam transfer or steam condensation on the skin that could cause second degree burns. 


\subsection{Test methods with moisture from pre-wetted samples}

Most test methods evaluating steam burns simulate moisture accumulation in the clothing system due to perspiration of fire fighters during strenuous fire suppression activities [34]. These methods assume that the fire fighters have sweated profusely and that sweat is absorbed by the fabric. The test specimen, therefore, includes pre-wetted fabric samples with varying amounts of moisture. A precise laboratory preconditioning protocol was developed [26] and further modified by Barker et al. [32]. The turnout composite was moistened to mimic moisture gradients that would occur in actual wear. Different moisture add-on levels and corresponding fire fighter conditions are given in Table 5 below.

Table 5. Moisture add-on levels and corresponding fire fighter conditions [32]

\begin{tabular}{|l|c|c|}
\hline Fire Fighter condition & Amount of water*, g & $\begin{array}{l}\text { \% by weight of turnout } \\
\text { gear system }\end{array}$ \\
\hline Dry & 0 & 0 \\
\hline $\begin{array}{l}\text { Sweating due to physical } \\
\text { exercising in warm environment }\end{array}$ & 2.5 & 15 \\
\hline Sweating at a rate of $1.5 \mathrm{~L} / \mathrm{h}$ & 8 & 50 \\
\hline Sweating at a rate of $3 \mathrm{~L} / \mathrm{h}$ & 16 & 100 \\
\hline
\end{tabular}

* Amount of water per $152 \mathrm{~mm}$ x $152 \mathrm{~mm}$ specimen.

Barker et al. studied effects of moisture on the thermal protective performance of heat-resistant fabrics [26] and fabric composites in firefighter's turnout gear [32]. In [32] they used a test set up (see Fig 2) to measure thermal protective performance of fabric composites exposed to low-level radiant heating. To reduce heat losses during testing, a water-cooled chamber was located around the perimeter of the test samples and the complete test apparatus was placed in a controlled environment. Such a test arrangement assumes that the fire fighter is exposed to dry radiant heat and that the presence of moisture in a clothing system is only due to sweat production. 


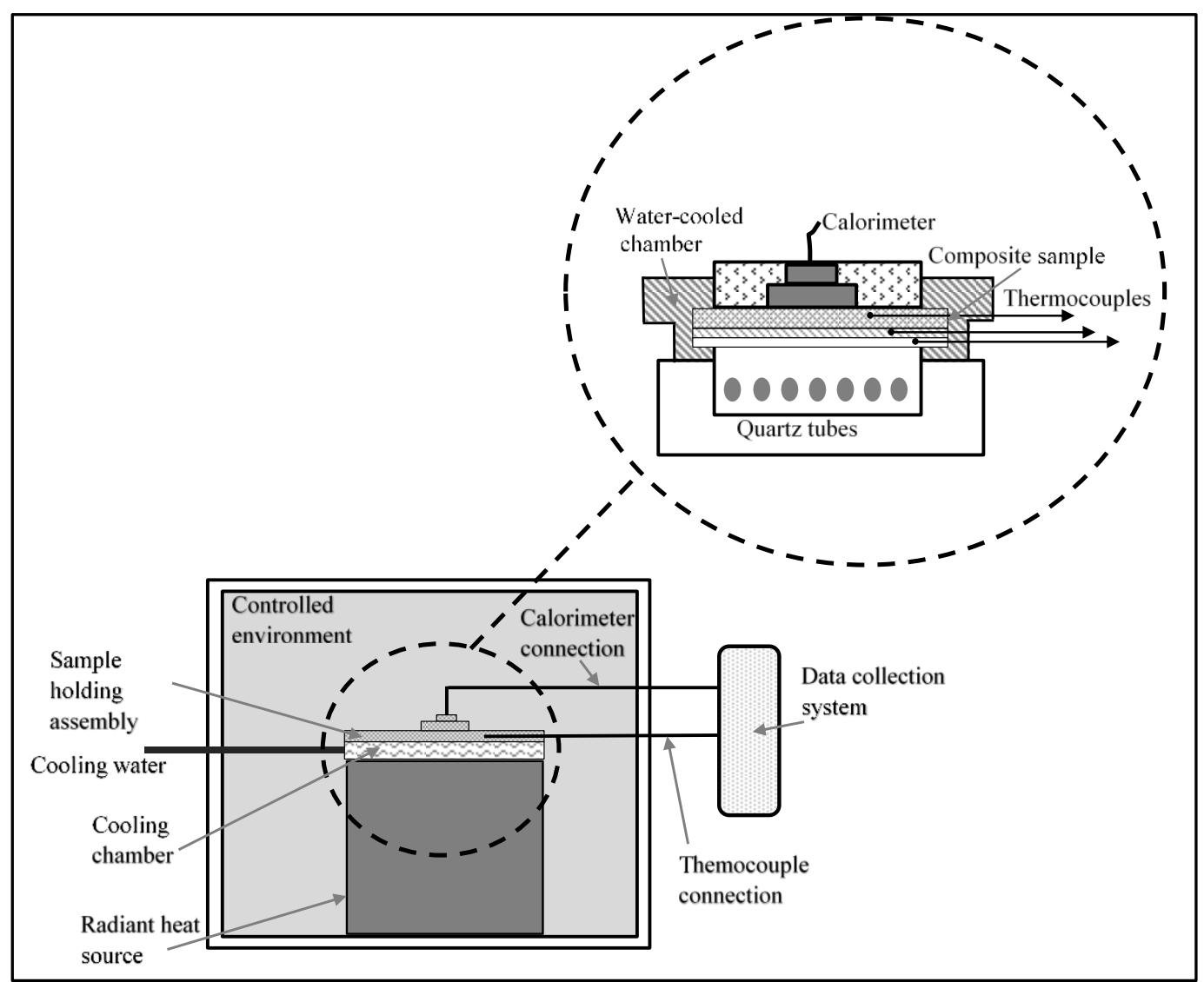

Figure 2. Test set up to measure thermal protective performance for low-level radiant exposures [32]

Zhu et al. [27] studied heat and moisture transfer behavior of single-layered flame retarded cotton fabric during combined drying and pyrolysis processes. The schematic of the test apparatus is shown in Fig. 3. A modified RPP test apparatus based on the NFPA 1977 [55] method was used. The heat source was provided by 13 quartz tubes of 500-watt power, horizontally oriented as opposed to the 9 vertically oriented quarts tubes used in the NFPA 1977 [ 55] RPP test method. The temperature rise and heat flux as a function of time was measured using a skin-simulating sensor instrumented with thermocouples. Weight loss of pre-wetted samples due to combined drying and pyrolysis was measured using a high resolution $(0.01 \mathrm{~g})$ electronic balance. 


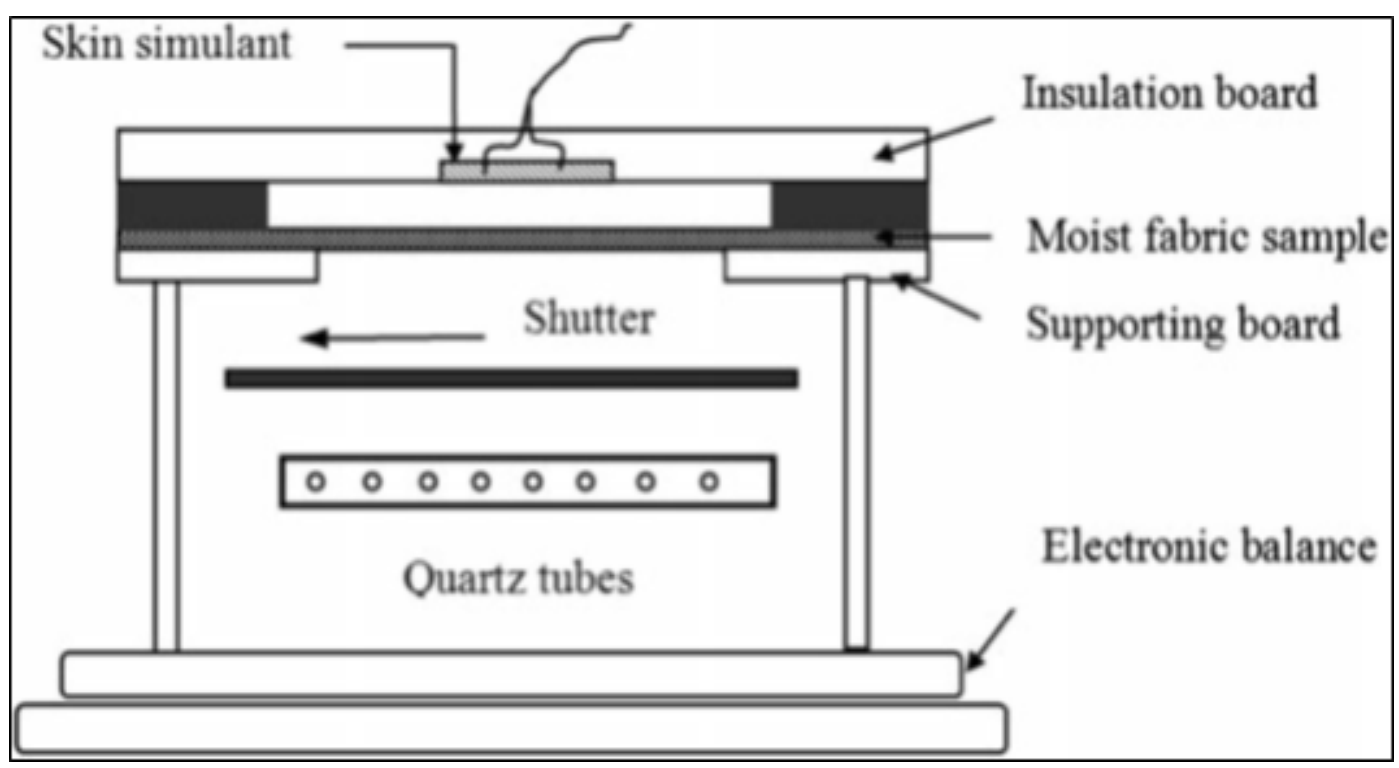

Figure 3. Test apparatus to assess radiant protective performance of fabrics [27]

In a separate study, Zhu and Zhou [28] studied heat and moisture transfer in pre-wetted, singlelayered fabrics made from inherently heat resistant fibers. In this study, they exposed the prewetted samples to two heat fluxes $\left(21 \mathrm{~kW} / \mathrm{m}^{2}\right.$ and $\left.42 \mathrm{~kW} / \mathrm{m}^{2}\right)$. The heat source was provided by a gas burner and corresponded to ISO 91541 (Protective clothing-Protection against heat and firedetermination of heat transmission on exposure to flame). An air gap of $50 \mathrm{~mm}$ was maintained between the fabric specimen and the copper calorimeter. A schematic of the test apparatus is shown in Fig. 4. The thermocouple embedded in the calorimeter measured temperature and the time for a temperature rise of $12{ }^{\circ} \mathrm{C}$ and $24{ }^{\circ} \mathrm{C}$ was recorded. Such experimental set up, however, records higher temperatures mainly by the condensing heat released by water condensation onto the surface of the copper calorimeter. The mass loss due to evaporation of moisture was determined by weighing fabric samples after heat exposure. The moisture mass-loss rate of prewetted fabrics was determined for a given heat flux by measuring mass-loss of heat exposed fabrics for different times. 


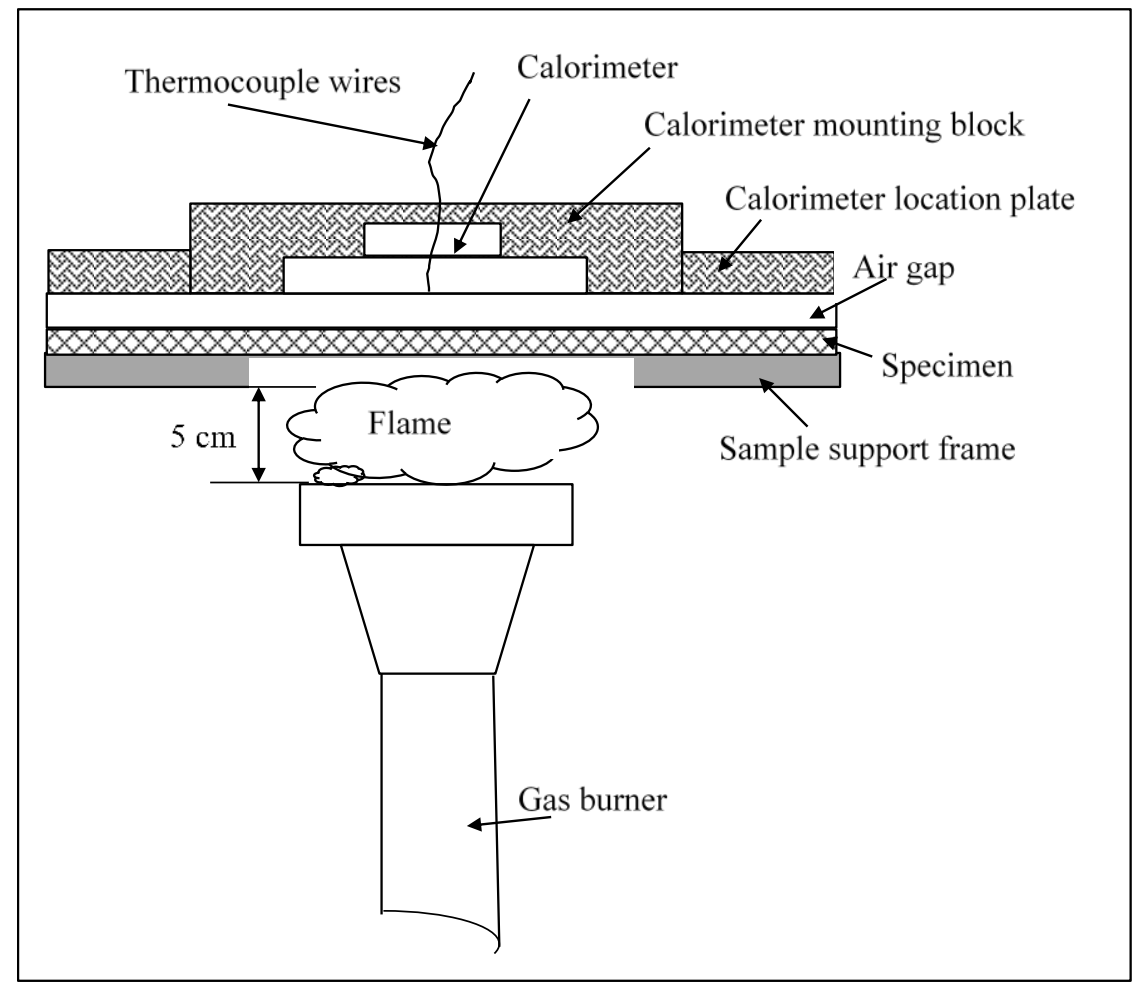

Figure 4. Schematic of experimental set up to assess protective performance of fabrics exposed to open flame [28]

Wakatsuki et al. [8] investigated heat transfer through a complete clothing system (including the FFPC, station wear, and underwear) under low incident heat fluxes $\left(12 \mathrm{~kW} / \mathrm{m}^{2}, 14 \mathrm{~kW} / \mathrm{m}^{2}\right.$, $17 \mathrm{~kW} / \mathrm{m}^{2}$, and $20 \mathrm{~kW} / \mathrm{m}^{2}$ ). They pre-wetted the station wear and/or the underwear to reproduce sweating in a fire fighter during fire suppression. Mean water content in the station wear (100\%) and underwear $(257 \%)$ was obtained by soaking respective fabrics in water. In all the tests, the FFPC was dry, assuming that the moisture barrier in the FFPC would prevent any moisture transmission from the inner layers to the outer turnout gear. They used an ISO 5660 cone heater as a heat source and a copper calorimeter was placed at the back of the clothing system (Fig. 5). The heat transfer index (HTI) and heat transfer rate for different test conditions (varying moisture location in the clothing system) was measured. While the study focused on heat transfer through pre-wetted samples, no attempt on investigating moisture transfer was made. 


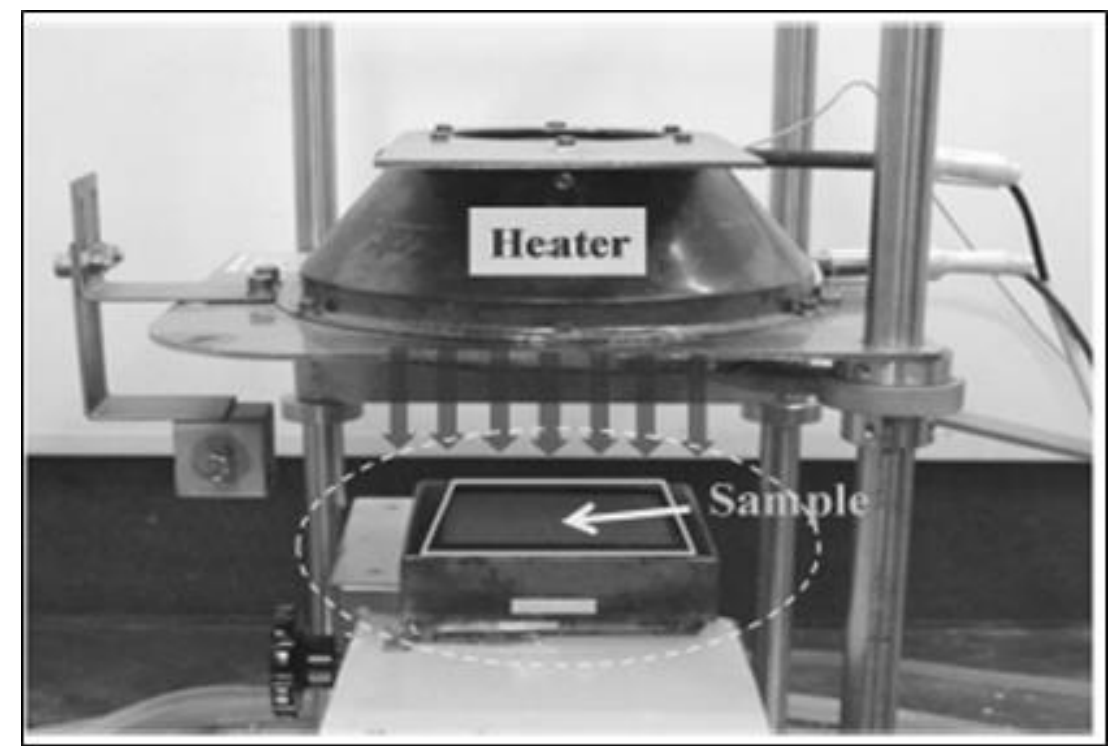

Figure 5. Schematic of test set-up to assess protective performance of pre-wetted fabrics [8]

In all of the test methods described above, the heat flux transferred through the test specimen is measured using a copper calorimeter. The heat flux data from the copper calorimeter are used to make human skin burn predictions using either the Stoll second degree burn criterion [56] or Henriques' burn integral [6]. Test specimens are rated based on the calculated time or the total incident heat energy required to reach second degree burns. However, it is worth noting here that such a test principle can only rank the test materials for their protective capabilities. Such a test principle cannot be employed to measure true protection offered by the test specimens [35]. The test specimen is exposed to a defined heat flux until a second degree burn criterion or a given sensor temperature is exceeded. These tests, however, do not provide any information about the first degree burns which might occur during or after exposure ends.

A systematic approach was adapted by Keirser and Rossi [34] to assess steam formation in multilayer FFPC at low-level thermal radiation. They used temperature measurements to predict evaporation rate within the clothing assembly. A schematic of the test apparatus used in their study is shown in Fig. 6. An infrared lamp was used as the source of constant radiant heat flux. The distance between the infrared lamp and the outer shell of the clothing assembly was positioned to supply a constant radiant heat flux of $5 \mathrm{~kW} / \mathrm{m}^{2}$. The clothing assembly, including the wet layer, was placed inside an upright standing polyether ether ketone (PEEK) tube and irradiated at $5 \mathrm{~kW} / \mathrm{m}^{2}$ for $10 \mathrm{~min}$. The test assembly was arranged such that moisture evaporating in the clothing system was not able to move sideways, thus minimizing convective heat transfer effects. T-type (copper- constantan) thermocouples were placed between each of the layers to measure the temperature distribution through the textile assembly. In their experiments, they found that during evaporation of moisture from pre-wetted internal layers of FFPC, there was no noticeable increase in the temperature. The energy consumption used for the phase change of moisture dominated the heat transfer process. They also noted that the moisture in the outer layers evaporated faster and at slightly higher temperatures than the moisture located in the inner layers. The authors indicated risk of steam burns by monitoring moisture condensation on the lid of the measuring unit and 
suggested that if the steam burns occurred, they might not be due to higher heat transfer under wet conditions, but more likely due to condensation of moisture on the skin.

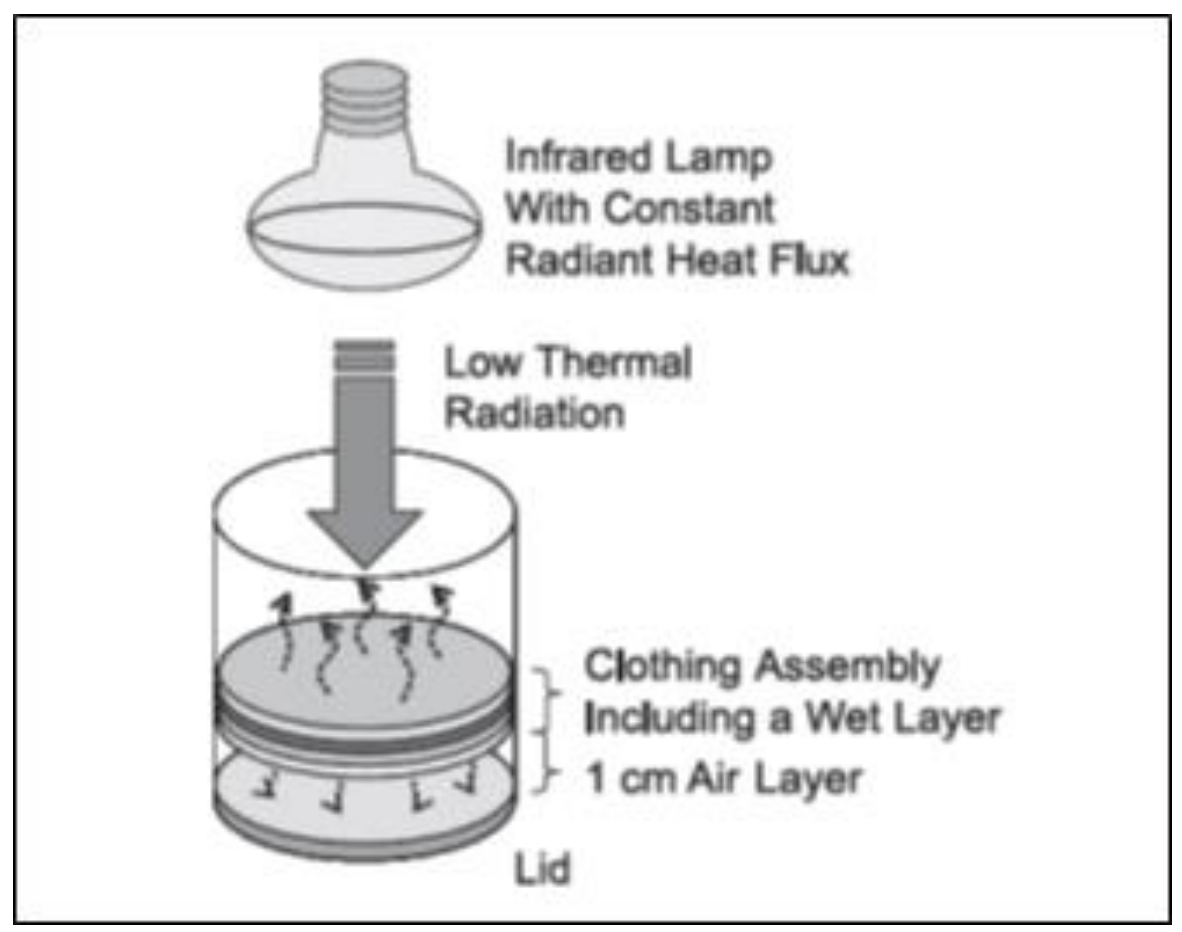

Figure 6. Schematic of test apparatus to measure temperature distribution in a clothing assembly exposed to low thermal radiations [34]

\subsection{Test methods with moisture from external steam exposures}

Compared to several studies [3, 8,19,23,24,27,28,32,34,67] that included pre-wetted samples, there are a limited number of studies wherein heat and moisture transfer in protective clothing was investigated by exposing dry samples to external steam. Derscuell and Schimid [36] developed a bench scale test as well as a full-scale thermal manikin test to study the effects of hot steam exposures on human physiology and protective capacities of fabrics respectively. The bench scale tests varied with steam exposure types. Schematics of bench scale test devices are shown in Fig. 7. Figure 7 (a) shows the steam jet configuration where the sample is movable and is exposed to a jet of steam. Figure 7 (b) shows a steam atmosphere configuration where a sample is stationary and a steam atmosphere is generated in an isolated box. Both devices included a steam generator, sample holder with thermo-regulated heat flux sensor, and a data acquisition system. The total and average amount of heat transfer through high-performance protective fabrics over a 10-min exposure time was measured at three different distances between the steam output and surface of the sample. Samples were classified by their physical characteristics and capacities to limit or modify heat transfer under the given steam exposures. 

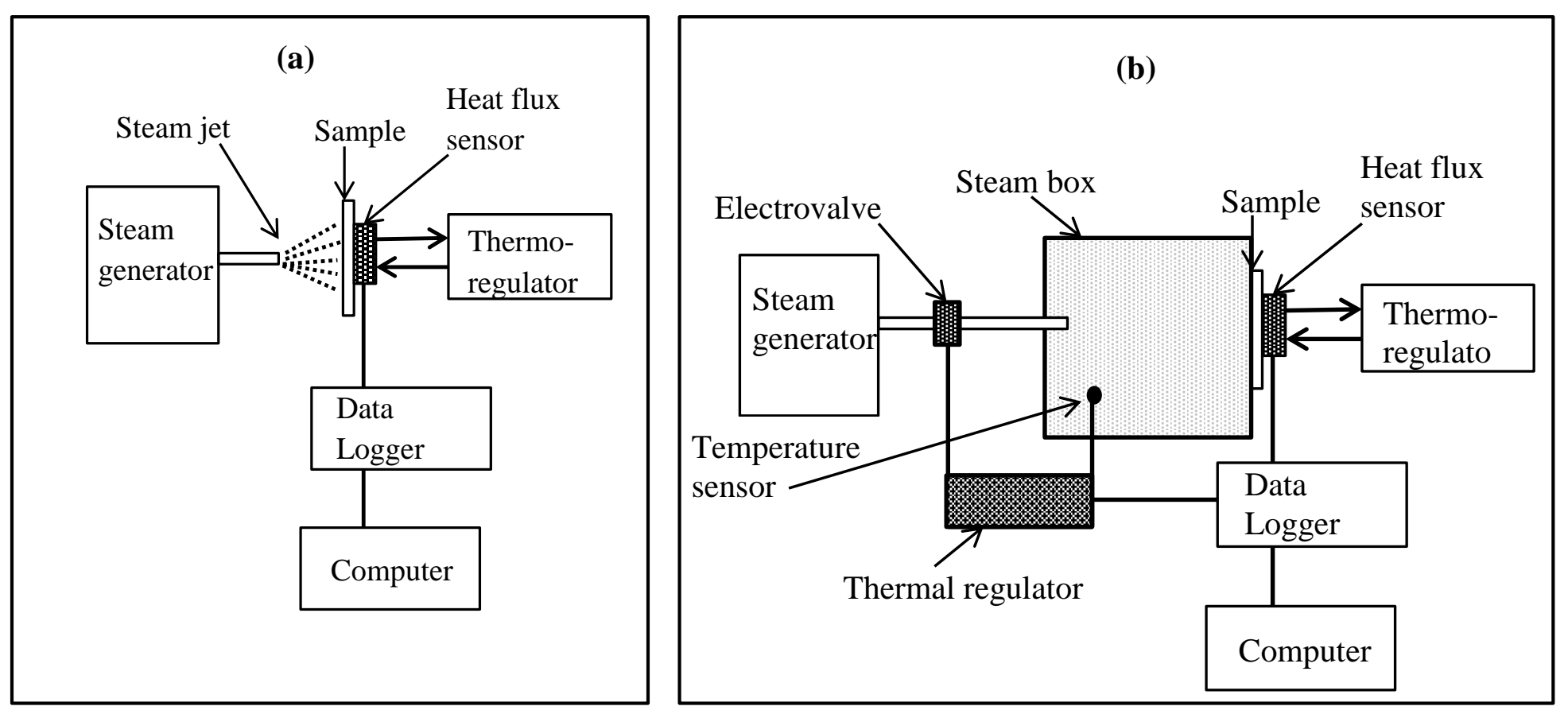

Figure 7. Schematic of bench scale test device with (a) steam jet and (b) steam atmosphere configurations [36] 
The protective performance of the garment was also evaluated in a steam chamber where the air temperature was maintained at $80{ }^{\circ} \mathrm{C}$ and the humidity was increased stepwise using a heating system and a humidifier. The researchers [36] failed to reach complete saturation within the chamber due to excessive condensation on the surface of a thermally-regulated manikin. A heat flux value at saturation was therefore extrapolated using exponential regression. The results of the bench-scale fabric test and the full-scale garment test with the manikin showed good correlation. The major limitation of Derscuell and Schimid's work [36] was that the heat flux sensors were thermally regulated, registering higher heat fluxes than would actually occur if the skin temperature was to rise with heat exposure.

A test device, similar to the one developed by Derscuell and Schimid [36], was developed by Sati et al. [37] to measure heat transfer through fabrics under high pressure steam exposures (207 $\mathrm{kPa}$ and $69 \mathrm{kPa}$ ). Steam exposure conditions in their studies simulated conditions in the oil and gas industry. Sati et al. [37] used a cylindrical mounting surface to simulate a human torso. Skin simulant sensors incorporating a colerceran ${ }^{2}$ (inorganic mixture of calcium, aluminum, silicate with asbestos fibers and a binder) plug and copper constantan thermocouples were mounted on the cylinder. Fabric samples were placed on the sensors with no air gap between the samples and the sensors. The peak temperature, peak heat flux, time to reach peak heat flux and total energy transferred during a $90 \mathrm{~s}$ time period (including a $10 \mathrm{~s}$ exposure time) were recorded to assess heat transfer properties of protective fabrics at two distances $(50 \mathrm{~mm}$ and $100 \mathrm{~mm}$ ) between cylinder and steam nozzle.

Rossi et al. [29] analyzed the steam transfer through multi-layer FFPC exposed to free flowing steam. The steam was produced by heating a water container with a Bunsen burner. A copper calorimeter with an attached thermocouple was used to measure the heat flux generated by the steam and to determine the rise in temperature at the back of the fabric specimen respectively. The steam produced a heat flux of $30 \mathrm{~kW} / \mathrm{m}^{2} \pm 2 \mathrm{~kW} / \mathrm{m}^{2}$. They defined the steam transfer index, $\mathrm{STI}_{12}$ as the time to reach a temperature increase of $12{ }^{\circ} \mathrm{C}$ and $\mathrm{STI}_{24}$ for an increase of $24^{\circ} \mathrm{C}$. The effects of sweating on heat and mass transfer were assessed by pre-wetting the fabric layers. However, since sweating is a continuing phenomena, Rossi et al. [29] used a "sweating" cylinder in a separate experiment to assess heat and mass transfer. The experiments showed contradicting effects of sweating on heat and mass transfer. Experiments with pre-wetted samples exhibited higher thermal conductivity and hence high heat transfer. Measurements with a sweating cylinder showed a beneficial effect of sweating. This result cannot be easily interpreted since a sweating cylinder is not fully representative of a human body as the metallic cylinder has a much higher thermal conduction than the human skin. This study, however, did not quantify the amount of steam transferred through the fabric ensemble.

Liu et al. [31] investigated protective performance of single-layer heat resistant fabrics with different air permeabilities under hot steam exposures. Their apparatus (see Fig. 8) consisted of four major parts: a steam chamber, the fabric, a copper calorimeter designed to simulate the human skin, and a data acquisition system. The test method used external pressurized steam and did not use pre-wetted fabric layers as a source of moisture. Two different steam pressure $(50.6 \mathrm{kPa}$ and $152 \mathrm{kPa}$ ) exposures were studied and samples were exposed for fixed period of $20 \mathrm{~s}$. The effect of different types of heat resistant fabrics on heat and moisture transfer was assessed at two steam

${ }^{2}$ Colerceran has thermal absorptivity similar to that of human skin. 
pressures and air-gap thicknesses (distance between the fabric and skin simulant). In this setup, the steam pressure pushed the fabric closer to the skin sensor, leading to compulsive hot steam transfer through the fabrics and higher thermal conduction.

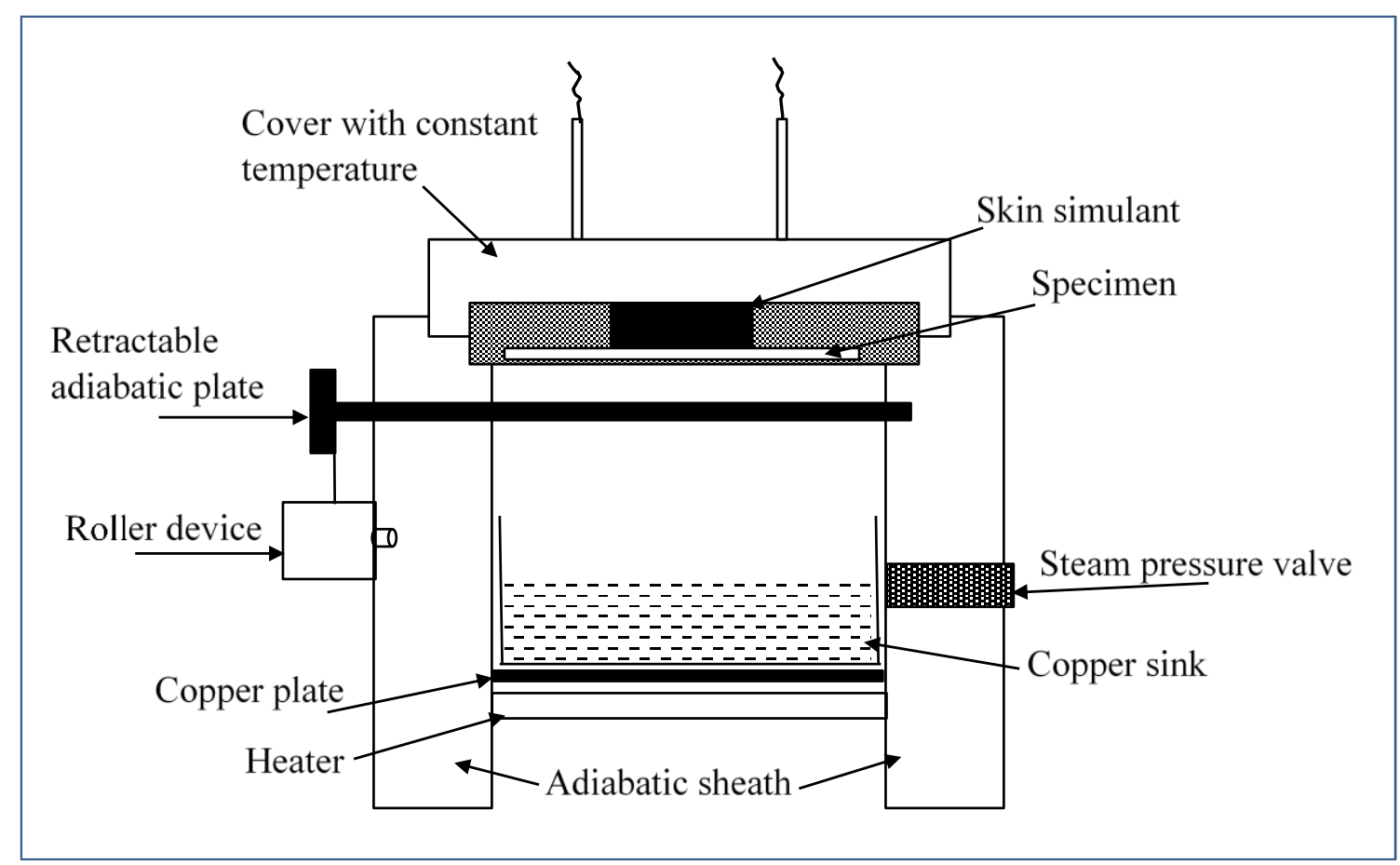

Figure 8. Schematic of experimental set up to assess protective performance of fabrics exposed to external pressurized steam [31]

Very recently Li et al. [30] studied effects of humidity in the air gaps between garment and skin on heat transfer properties under flash fire conditions. They modified the TPP apparatus (Fig. 9) to accommodate the microclimate between the specimen and the sensor. They used a commercial ultrasonic atomizing humidifier to generate water vapor with a temperature of $33{ }^{\circ} \mathrm{C} \pm 1{ }^{\circ} \mathrm{C}$. Three microclimates with three relative humidities $(35 \%, 65 \%$, and $95 \%)$ were investigated. Their findings suggested that the $\mathrm{RH}$ in a microclimate improves thermal protective performance of fabrics by $18 \%$ to $33 \%$, depending on the air gap, i.e. the height of the microclimate chamber. They proposed that the water droplets in the microclimate evaporate due to high temperature and absorb heat, thereby reducing the heat energy transferred from the heated fabric to the thermal sensor. The authors, however, failed to measure moisture absorption and transmission properties of fabrics using the modified TPP apparatus. The experimental set up in their study addresses clothing microclimates under human sweating. It does not, however, take into consideration external humidity that a firefighter may encounter during fire suppression activities. 


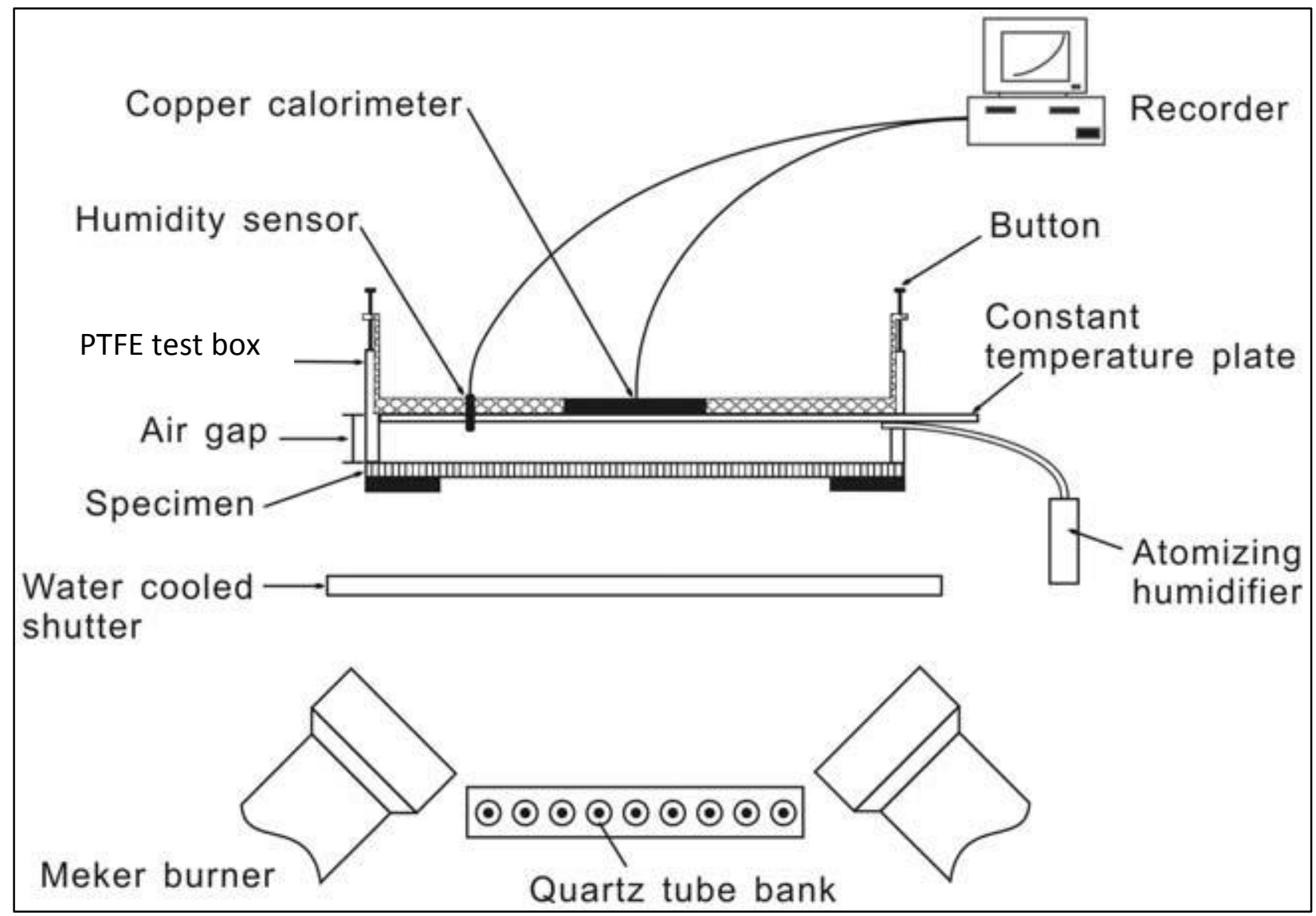

Figure 9. Schematic of TPP test apparatus with modified specimen assembly to accommodate microclimate between the specimen and the copper calorimeter [30]

Ackerman et al. [38] developed a test method and associated apparatus to evaluate protective performance of fabrics against industrial, low pressure steam hazards. The bench-scale test apparatus (Fig. 10) facilitates steam exposure conditions over range of pressures (69 $\mathrm{kPa}$ to $620 \mathrm{kPa}$ ) for both saturated and superheated steam. Superheated steam was produced by electrically heating the saturated steam generated in a boiler. The computer program controls the steam conditions, exposure time and also monitors the sensor output. Researchers also developed a sample holder to accommodate impermeable membranes in the test specimen. This essentially avoided any undue buildup of pressure and thereby heat transfer. The test output in the form of peak heat flux and total absorbed energy enabled differentiation amongst fabrics and/or fabric systems.

The steam exposure conditions used in the test methods described in this section are summarized in Table 6. It is clear from the table that almost all exposures are high steam pressures. Even the test apparatus described by Ackerman et al. [38], employs steam pressure that is significantly higher than the pressures encountered during structural firefighting. Differential pressures of $50 \mathrm{~Pa}$ above ambient or less are typically noted in a fire room [68]. Clearly, a test device and test method is required where the steam exposure conditions simulate the thermal/water vapor conditions encountered during structural firefighting. 


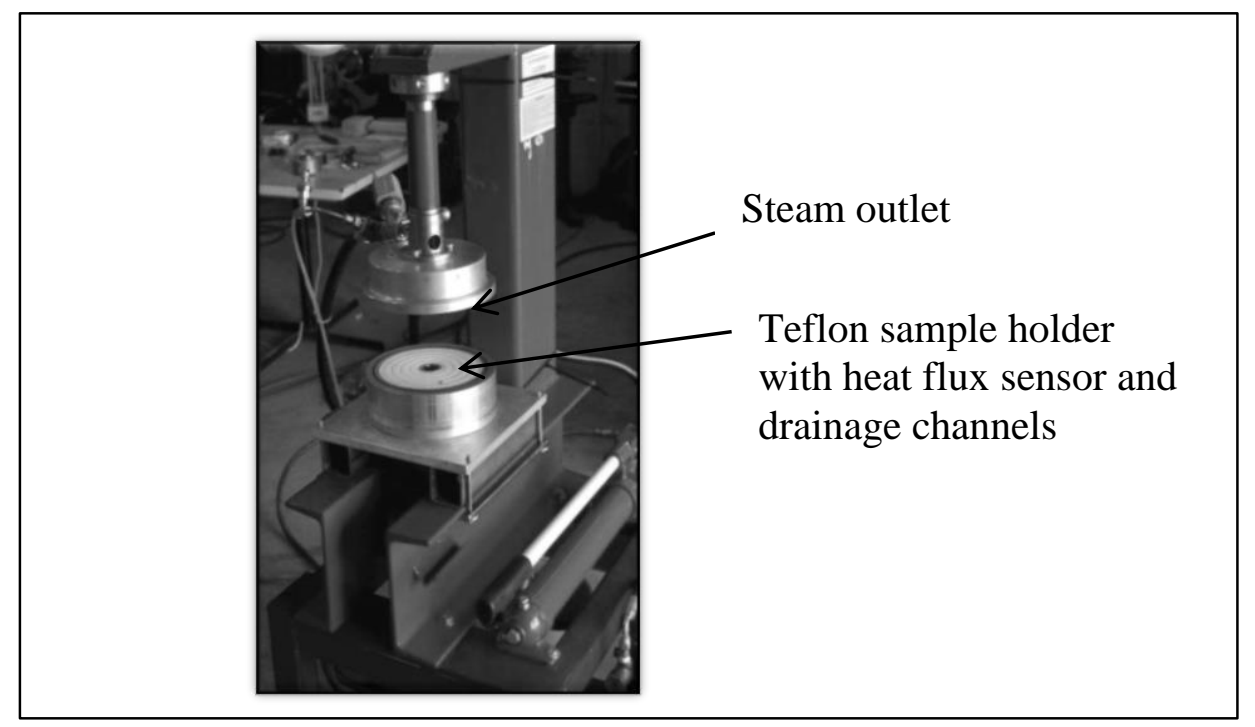

Figure 10. Apparatus for evaluation of fabric protection against industrial steam hazard [38]

Table 6. Steam exposure conditions previously studied

\begin{tabular}{|l|l|l|l|l|l|}
\hline $\begin{array}{l}\text { Steam } \\
\text { configuration }\end{array}$ & $\begin{array}{l}\text { Distance*, } \\
\text { mm }\end{array}$ & $\begin{array}{l}\text { Temperature, } \\
\mathbf{o} \mathbf{C}\end{array}$ & $\begin{array}{l}\text { Pressure, } \\
\text { kPa }\end{array}$ & $\begin{array}{l}\text { Exposure } \\
\text { time, s }\end{array}$ & Reference \\
\hline Jet & NA & 140 & 300 & 600 & $\begin{array}{l}\text { Derscuell and } \\
\text { Schimid [36] }\end{array}$ \\
\hline $\begin{array}{l}\text { Steam } \\
\text { atmosphere in an } \\
\text { enclosure }\end{array}$ & NA & 80 & NA & NA & $\begin{array}{l}\text { Derscuell and } \\
\text { Schimid [36] }\end{array}$ \\
\hline Jet & 50 to 100 & 115 to 134 & 69 to 207 & 10 & Sati et al.[37] \\
\hline $\begin{array}{l}\text { Steam } \\
\text { atmosphere in an } \\
\text { enclosure }\end{array}$ & - & 112 to 128 & $\begin{array}{l}50.6 \text { to } \\
152\end{array}$ & 20 & Liu et al. [31] \\
\hline $\begin{array}{l}\text { Steam } \\
\text { atmosphere in an } \\
\text { enclosure }\end{array}$ & NA & 33 & NA & $* *$ & Li et al. [30] \\
\hline \begin{tabular}{l} 
Jet \\
\hline
\end{tabular} & 50 to 150 & NA & 69 to 620 & 10 & $\begin{array}{l}\text { Ackerman } \\
\text { et al.[38] }\end{array}$ \\
\hline
\end{tabular}

* Distance between steam jet and heat sensor.

** Exposure until occurrence of $2^{\text {nd }}$ degree skin burn.

NA: not available.

\section{Summary and Conclusions}

A review of the literature suggests that research on heat and moisture transfer mechanisms in FFPC has primarily focused on moisture generated due to excessive sweating of the firefighters and subsequent exposure to high-risk environments including flash-over exposures. The effect of external moisture and thereby the heat transfer through protective clothing has received very little attention. 
It is evident that the moisture present in a protective clothing system has a complex influence on heat transmission and potential for skin burn injuries. In all of the above studies, test devices measured heat transfer through the clothing system either in the presence of high pressure external steam or internal moisture. The time to second degree burn is often used for evaluating thermal protective performance of fabrics. Available test methods for estimation of steam burns are insufficient as they provide static values that are achieved by testing the specimen under one defined condition. There is no test method available for evaluating effects of simultaneous diffusion of external steam and evaporation of moisture generated due to sweating on formation of steam burns. A major obstacle in the development of such testing methodologies is the lack of basic understanding of how moisture is absorbed in turnout clothing systems when exposed either to perspiration from sweating fire fighters or to water from fire suppressing activities. Better understanding of mass and heat transfer in fire fighters' protective clothing will help the development of better engineered clothing systems to accommodate a wide range of environments and reduce steam burns in fire fighters.

An advanced physical model of the heat and mass transfer in FFPC would provide better understanding of water vapour absorption, diffusion, and evaporation within the protective layers exposed to hot and humid environments. Application of such an advanced physical model would allow optimisation and improved design of next generation FFPC. 


\section{References}

[1] J. R. Lawson, Thermal performance and limitations of bunker gear, Fire Engineering August (1998).

[2] C. V. Le, N. G. Ly, and R. Postle, Heat and mass transfer in the condensing flow of steam through an absorbing fibrous medium, International Journal of Heat and Mass Transfer 38(1), 81-89 (1995).

[3] L.K. Lawson, E. M. Crown, M. Y. Ackerman, and J. D. Dale, Moisture effects in heat transfer through clothing systems for wildland firefighters, International journal of Occupational Safety and Ergonomics 10 (3), 227-238 (2004).

[4] SFPE Task Group on Engineering Practices, "Predicting 1st and 2nd Degree Skin Burns from Thermal Radiation," Society of Fire Protection Engineers, Bethesda, MD, 2000.

[5] R. Rossi Experimental investigation of the interaction of protection and physiology in fire fighters' protective clothing, The Institute of Hygiene and Applied Physiology at ETH Zurich.

[6] F. C. Henriques, A. R. Moritz, Studies of Thermal Injury: The Conduction of Heat Through Skin and the Temperatures Attained Therein. A Theoretical and Experimental Investigation, American Journal of Pathology, (1947).

[7] I. Hymes, The Physiological and Pathological Effects of Thermal Radiation, United Kingdom Atomic Energy Authority, SRD/HSE R275, 1983.

[8] K. Wakatsuki, N. Morii, Y. Ogawa, and H. Tsuji, Influence on skin burns by water absorbed station wear and underwear in firefighting clothing, Advanced Materials Research (2013), 796: 623-629.

[9] J. H. Veghte Effect of moisture on the burn potential of fire fighters gloves, Fire Technology 23 (4), 313-322 (1987).

[10] T. A. Braus, R. P. Dutrieux, M. J. Hoekstra, R. W. Kreis, and J. S. DuPont, Histopathological evaluation of scalds and contact burns in the pig model, Burns 20, 4851 (1994).

[11] J. D. Wiseman Jr., The myth of superheated steam, Physics L archives, August 1999. Available from: http://www.phys-1.org/archives/1999/08_1999/msg00919.html

[12] J. H. Veghte, Physiologic response of fire fighters structural and hazmat protective clothing, Second annual conference on protective clothing, Clemson University, May 1988.

[13] I. Holmér, Protective clothing in hot environments, Industrial Health 44, 404-413(2006).

[14] J. Lawson, W. D. Walton, N. P. Bryner, and F. K. Amon, Estimates of thermal protective properties for fire fighters' protective clothing materials. NISTIR 7282, National Institute of Standards and Technology, June 2005.

[15] J. Lawson, and T. A. Pinder, Estimates of thermal conductivity for materials used in fire fighters' protective clothing. NISTIR 6512, National Institute of Standards and Technology, May 2000.

[16] F. Zhu, and W. Zhang, Measuring the thermal conductive property of protective fabrics to radiant heat exposure, Journal of Industrial Textiles 37, 175-186 (2007).

[17] T. Haran, Short-wave infrared diffuse reflectance of textile materials, Doctoral Thesis, Georgia State University, 2008. Available from: http://scholarworks.gsu.edu/cgi/viewcontent.cgi?article=1004\&context=phy_astr_theses 
[18] H. S. Yoo, G. Sun, and N. Pan, Thermal protective performance and comfort of wildland firefighter clothing: the transport properties of multilayer fabric system, Performance of Protective clothing: Issues and Priorities for the 21st Century: Seventh Volume, ASTM STP 1386 C. N. Nelson and N. W. Henry, eds., American Society for Testing Materials, West Conshohocken, PA, 2000, pp 504-518.

[19] Z. Cui, and W. Zhang, Study of the effect of material assembly on the moisture and thermal protective performance of firefighter clothing, Fibres \& Textiles in Eastern Europe 17(6), 80-83 (2009).

[20] J. A. Wehner, L. Rebenfeld, and B. Miller, Dynamic moisture sorption and transport characteristics of textile materials, Lenzinger Berichte 58, 48-52(1985). Also available from:

http://www.lenzing.com/fileadmin/template/pdf/konzern/lenzinger berichte/ausgabe 58_1985/LB_1985_0 7.Wehner.pdf

[21] Y. Li and Q. Zhu, Simultaneous heat and moisture transfer with moisture sorption, condensation and capillary liquid diffusion in porous textiles, Textile Research Journal 73(6), 515-524 (2003).

[22] Y. Wang, Y. Zong, J. Li and M. Zhao, Evaluating the moisture transfer property of the multi-layered fabric system in firefighter turnout clothing, Fibres \& Textiles in Eastern Europe 19(6), 101-105 (2011).

[23] P. Chitrphiromsri and A. V. Kuznetsov, Porous medium for investigating transient heat and moisture transport in firefighter protective clothing and high-intensity thermal exposure, Journal of Porous Media 8(5), 511-528 (2005).

[24] P. Chitrphiromsri and A. V. Kuznetsov, Modelling heat and moisture transport in firefighter protective clothing during flash fire exposure, Heat and Mass Transfer 41, 206215 (2005).

[25] C. Keiser Steam burns: Moisture management in firefighter protective clothing. A dissertation submitted to the Swiss Federal Institute of Technology, Switzerland (2007).

[26] Y. M. Lee and R. L. Barker, Effect of moisture on the thermal protective performance of heat-resistant fabrics, Journal of Fire Sciences 4, 315-330 (1986).

[27] F. Zhu and K. Li, Numerical modeling of heat and moisture through wet cotton fabric using the method of chemical thermodynamic law under simulated fire, Fire Technology 47, 801819 (2011).

[28] F. L. Zhu and Y. Zhou, Modelling heat-moisture transport through firefighters' protective fabrics from an impinging flame jet by simulating the drying process, Fibres and Textiles in Eastern Europe 21(101), 85-90 (2013).

[29] R. Rossi, E. Indelicato and W. Bolli, Hot steam transfer through heat protective clothing layers, International Journal of Occupational Safety and Ergonomics (JOSE) 10(3), 239245 (2004).

[30] J. Li, Y. Lu, and X. Li Effect of relative humidity coupled with air gap on heat transfer of flame-resistant fabrics exposed to flash fires, Textile Research Journal 82, 1235-1243 (2012).

[31] H. Liu, Z. Cui, F. Zhu, and W. Zhang, Investigation of protective performance of heat resistant fabrics under external hot steam exposures. In proceedings of the third international conference on Modelling and Simulation (ICMS2010) Volume 4: Modelling and Simulation in Biology, Ecology and Environment, Wuxi, People's Republic of China, June 4-6, 2010. 
[32] R. L. Barker, C. Guerth-Schacher, R. V. Grimes and H. Hamouda, Effects of moisture on the thermal protective performance of firefighter protective clothing in low-level radiant heat exposures, Textile Research Journal (2006), 76: 27-31.

[33] K. Prasad, W. Twilley, and J. R. Lawson, Thermal performance of fire fighters' protective clothing. 1. Numerical study of transient heat and water vapor transfer. NISTIR 6881, National Institute of Standards and Technology, August 2002.

[34] C. Keiser and R. M. Rossi, Temperature analysis for the prediction of steam formation and transfer in multi-layer thermal protective clothing at low level thermal radiation, Textile Research Journal 78, 1025- 1035 (2008).

[35] D. A. Trovi, J. D. Dale, M. Y. Ackerman and E. M. Crown, A study of new and existing bench top tests for evaluating fabrics for flash fire protective clothing, Performance of Protective Clothing: Sixth volume, ASTM STP 1273, J. O. Stull and A. D. Schwope, eds., American Society for Testing and Materials, 1997.

[36] A. V. Desruelle and B. Schmid, The steam laboratory of the institute de médecine navale du service de santé des armées: a set of tools in the service of the French Navy, European Journal of Applied Physiology, 92, 630-635 (2004).

[37] R. Sati, E. M. Crown, M. Ackerman, J. Gonzalez, and D. Dale Protection from steam at high pressures: Development of a test device and protocol, International journal of Occupational Safety and Egronomics 14(1), 29-41(2008).

[38] M. Y. Ackerman, E. M. Crown, J. D. Dale, G. Murtasa, J. Batcheller and Gonzalez, Development of a test apparatus/method and material specifications for protection from steam under pressure, Performance of Protective Clothing and Equipment: Emerging Issues and Technologies on 16 April 2011 in Anaheim, CA; STP 1544, A. M. Shepherd, Guest edt., pp. 1-21, ASTM International, West Conshohocken, PA 2012. doi:10.1520/STP104104,

[39] A. M. Stoll, M. A. Chianta, and L. R. Munroe, Flame-contact studies, Journal of Heat transfer 86, 499-456 (1964).

[40] D. A. Trovi, D. Dale, and B. Faulkner, Influence of air gaps on bench-top test results of flame resistant fabrics, Journal of Fire Protection Engineering 10 (1), 1-12 (1999).

[41] G. Song, Clothing air gap layers and thermal protective performance in single layer garment, Journal of Industrial Textiles 36(3), 193-205 (2007).

[42] H. Song, H. Dongmei, Q. Zhengkun, Y. Hui, H. Yin, and H. Zhang, The effect of air gap thickness on heat transfer in firefighters' protective clothing under conditions of short exposure to heat, Heat Transfer Research 43(8), 749-76 (2012).

[43] K. H. Umbach Physiological tests and evaluation models for the optimization of the protective clothing, In Environmental Ergonomics, I. B. Mekjavic, E. W. Banister, J. B. Morrison, eds., Taylor and Francis, New York (1988) pp.139-161.

[44] Fournier M., Duvaut T., Chirtoc M and Bachmann JM. Measurement of textile thermal properties, European Physical Journal Special Topics (2008), 153: 143-145.

[45] L. Hes, Non-destructive determination of comfort parameters during marketing of functional garments and clothing, Indian Journal of Fiber and Textile Research 33, 239245 (2008).

[46] ASTM F 1868: Standard Test Method for Thermal and Evaporative Resistance of Clothing Materials Using a Sweating Hot Plate.

[47] ASTM E96: Standard Test Methods for Water Vapor Transmission of Materials. 
[48] ISO 11092: Textiles- Physiological effects- Measurement of thermal and water-vapour resistance under steady-state conditions (sweating guarded-hotplate test).

[49] ASTM F 1291: Test Method for Measuring the Thermal Insulation of Clothing Using a Heated Manikin.

[50] ASTM F2370: Standard Test Method for Measuring the Evaporative Resistance of Clothing Using a Sweating Manikin.

[51] ASTM F2371: Standard Test Method for Measuring the Heat Removal Rate of Personal Cooling Systems Using a Sweating Heated Manikin.

[52] ASTM F 2298 : Standard Test Methods for Water Vapor Diffusion Resistance and Air Flow Resistance of Clothing Materials Using the Dynamic Moisture Permeation Cell

[53] ISO 15831: Clothing -Physiological effects- Measurement of thermal insulation by means of a thermal manikin.

[54] NFPA 1971: Standard on protective ensembles for structural firefighting and proximity firefighting.

[55] NFPA 1977: Standard on protective clothing and equipment for wildland firefighting.

[56] A. M. Stoll, M. A. Chianta, Method and rating system for evaluation of thermal protection, Aerospace Medicine 40(11), 1232-1237 (1996).

[57] ASTM F2702: Standard Test Method for Radiant Heat Performance of Flame Resistant Clothing Materials with Burn Injury Prediction.

[58] ASTM F2703: Standard Test Method for Unsteady-State Heat Transfer Evaluation of Flame Resistant Materials for Clothing with Burn Injury Prediction.

[59] ISO 17492: Clothing for protection against heat and flame- Determination of heat transmission on exposure to both flame and radiant heat

[60] ASTM F1939: Standard Test Method for Radiant Heat Resistance of Flame Resistant Clothing Materials with Continuous Heating.

[61] ASTM F2731: Standard Test Method for Measuring the Transmitted and Stored Energy of Firefighter Protective Clothing Systems.

[62] ISO 9151: Protective clothing against heat and flame- Determination of heat transmission on exposure to flame.

[63] ASTM F1060: Standard Test Method for Thermal Protective Performance of Materials for Protective Clothing for Hot Surface Contact.

[64] ASTM F1930: Standard Test Method for Evaluation of Flame Resistant Clothing for Protection Against Fire Simulations Using an Instrumented Manikin.

[65] ASTM F955: Standard Test Method for Evaluating Heat Transfer through Materials for Protective Clothing Upon Contact with Molten Substances.

[66] ISO 9185: Protective clothing- Assessment of resistance of materials to molten metal splash.

[67] F. Zhu, Z. Weiyuan, and C. Minzhi, Investigation of materials combinations for firefighter's protective clothing on radiant protective and heat-moisture transfer performance, Fibres \& Textiles in Eastern Europe 15(1), 72-75 (2007).

[68] S. Kerber and W.D. Walton, Effect of Positive Pressure Ventilation on a Room Fire. NISTIR 7213, National Institute of Standards and Technology, December 2005. 